\title{
Income Mobility of Owners of Small Businesses when Boundaries between Occupations are Vague
}

\author{
THOR O. THORESEN
}

CESIFo WORKING PAPER NO. 2633

CATEgORY 1: Public FinANCE

APRIL 2009

An electronic version of the paper may be downloaded

- from the SSRN website:

- from the RePEc website:

- from the CESifo website:

www.SSRN.com

www.RePEc.org

www.CESifo-group.org/wp 


\title{
Income Mobility of Owners of Small Businesses when Boundaries between Occupations are Vague
}

\begin{abstract}
Ownership of small businesses can facilitate upward mobility through the income hierarchy and help individuals maintain a place at the higher end of the income distribution hierarchy. This paper compares the positional stability of owners of small businesses with that of wage earners, arguing that describing the relative position of different occupations faces definitional challenges. For instance, the Norwegian dual income tax system encourages owners of small businesses to establish widely held firms, with themselves as employees, because it reduces the tax burden and increases post-tax income. Descriptions of income distribution mobility of different occupations are therefore in danger of being misleading if such occupational measurement problems are not taken into account. I discuss in this paper the income mobility of owners of small firms in Norway 1993-2003 by estimating income transition models for different definitions of occupational status. Business ownership facilitates upward mobility and helps owners maintain a place at the top of the income distribution scale, and wider definitions of what counts as a small business owner enhance these correlations. However, as the paper shows, business owners are more mobile than wage earners and therefore overrepresented at the lower and higher ends of the income distribution ranking, irrespective of definition.
\end{abstract}

JEL Code: D31, H25, H30.

Keywords: income mobility, dual income tax, income of owners of small businesses, random effects model.

\author{
Thor O. Thoresen \\ Research Department \\ Statistics Norway \\ P.O. Box 8131 \\ Norway - 0033 Oslo \\ thor.olav.thoresen@ssb.no
}

This work has been supported by Grant 158143/S20 from the Norwegian Research Council. In the preparation of this study I benefited from a research stay at CES in Munich; the generous hospitality of the institute is gratefully acknowledged. I would also like to thank Bård Lian and Elin Halvorsen for their assistance in the preparation of this study, and Peter Lambert for his comments to an earlier version of the paper. 


\section{Introduction}

Policy-makers are paying increasing attention to the economic conditions under which owners of small firms operate, not least because small businesses are considered to be vital to economic growth, innovation and the dynamics of economic systems. This concern for the small business is reflected in tax policies. For instance, the low, flat-rate capital income tax that is common to the dual income tax systems of Norway and the other Nordic countries was designed to encourage entrepreneurial initiative and other business activities. In this paper we ask whether owners of small businesses have experienced any improvement in their position on the income scale (relative to wage earners) in the period from 1993 to 2003. This particular timeframe was chosen because the dual income tax system came into force in Norway in 1992. ${ }^{1}$ Insofar as dual income tax systems are clearly of some considerable interest to policy-makers worldwide, it is desirable to obtain information about effects of such tax systems on, for instance, the performance of owners of small businesses.

A main point of this paper is that identifying business owners in the data is a significant challenge, a problem exacerbated by the dual income tax system. The present study uses income statistics for persons and families compiled by Statistics Norway (2006a). They include information obtained from income tax returns for the whole population for every year between 1993 and 2003. As the whole population is covered, it is a rich source of information. However, owners of incorporated businesses are categorized as employees in these data, whereas in most other respects they are classified as business owners, similar to the self-employed. This is a definitional measurement problem in many countries, including the US and the UK (Parker, 2004).

The Norwegian dual income tax system exacerbated the problem. It levyed a flat 28 percent tax rate on corporate income, capital and labor income, and then imposed a progressive surtax schedule on labor income, taxing wage income at 49.5 percent at the margin. ${ }^{2}$ While this system did away with the double taxation of dividends and gave tax-payers full credit for dividend payments at the corporate level, the capital gains taxation system introduced a valuation system to control for gains already paid for through retained firm profit. However, as these disparate schedules for capital and labor income threatened to increase the likelihood of income shifting, preventive regulations were enforced with the introduction under the tax reform of 1992 of what was known as the split model of taxation for the self-employed and closely held firms (i.e., firms in which more than two-thirds of the shares are held by one person). Under this model, business income was divided into a capital and a labor income tax base, the latter being subject to surtax. Owners of closely held firms are normally

\footnotetext{
${ }^{1}$ A reformed tax system was put in place in 2006, see Sørensen (2005).

${ }^{2}$ This is according to the schedule of 1993, in which the second tier of the surtax was applicable for incomes above NOK 230,000 (US\$ 32,500 according to exchange rates for 2003, 1USD=7.08 NOK, which we use in this paper).
} 
categorized as wage earners. With the split model, owners of small businesses could incorporate as a widely held firm, with an ownership share of less than two-thirds. These active owners are classified as employees, but could still take advantage of the gap between capital and wage income taxation by being paid in terms of dividends instead of salary. Thoresen and Alstadsæter (2008) find that some of the features of the dual income tax work in combination with some of the features of human capital intensive businesses to facilitate organizational shifts, providing substantial income gains for the people involved. The evidence presented here substantiates some of the implications of these shifts with regard to the overall economic advancement of business owners.

Small business ownership can take one of three organizational forms: the owner can be denominated as self-employed (or sole proprietor); ownership can take the form of the closely held firm under the split model; or, finally, as the widely held firm. Business owners who incorporate as one of the two latter options are classified as wage earners, even though their activities are very similar to those of the self-employed. Under these circumstances, allowing the self-employed to represent owners of small businesses when discussing the effects of business ownership on income growth, we are in danger of seriously misleading our audience.

In exploring such definitional challenges, the paper shows that owners of small businesses do in fact operate under various organizational forms, and that different tax systems can affect the significance of this definitional problem. To identify owners of small businesses characterized as widely held firms, we compare data retrieved from the newly established Register of Shareholders with data from the End of the Year Certificate Register. ${ }^{3}$ This allows us to discuss the relationship between income gain and business ownership for different definitions of business owner, applying a wide definition that incorporates owners whose businesses are classified as widely held firms.

Previous contributions on mobility of business owners, see e.g., Holtz-Eakin et al. (2000), Fairlie (2004; 2005), note that running a business creates an opportunity for upward mobility for disadvantaged groups. Given the emphasis of the present study on business owners involved in tax avoiding organizational shifts and ownership of small businesses as a means of getting rich and staying rich, our focus is on the effect on the upper part of the income distribution. Of course, we could have used cross-sectional data to examine relationships, identifying the number of business owners in the upper part of the income distribution in repeated cross-sections over the period. However, by adopting a longitudinal perspective we get a better understanding the relationship between business ownership and income over time. The main approach of the present paper is to discuss income mobility by estimating transition rates, using various definitions of income hierarchy movement as the dependent variable and focusing on business ownership as an explanatory variable,

\footnotetext{
${ }^{3}$ See Statistics Norway (2006b) and Statistics Norway (2006c) for documentation of the two registers, respectively.
} 
also controlling for observed characteristics and unobserved individual effects. We want to know whether business ownership induces upward mobility in the income hierarchy and whether business ownership helps owners maintain a position at the high end of the income distribution.

The paper is organized as follows. Section 2 reviews earlier studies on the relationship between occupation and income mobility. Section 3 presents the register data used in this study. We also ask here whether the individual level data we have available for this study replicate household level trends in income inequality before discussing initial evidence from mobility tables. In Section 4 we probe deeper into correlations between business ownership and placement in the income distribution by estimating a random effects transition model. Section 5 closes the paper.

\section{Discussions in the literature on the relationship between involvement in small businesses and income mobility}

When analyzing the relationship between income and business activities, it is important to note that there is no obvious direction of causality; occupational choice and income will often be seen as simultaneous variables. In the occupational choice literature, incomes or yields in different states, e.g., in wage employment or self-employment, are used as explanatory variables.

The main ambition of the present study is to assess the effect of involvement in business activities on income development. In that respect the present study aligns itself with the literature on entrepreneurship and self-employment as a means of upward mobility in the income hierarchy. This means that the occupational choice variable crosses over to the explanatory variables. A number of papers by Fairlie discuss business ownership and entrepreneurship as a route out of poverty and unemployment for disadvantaged families. Two of them (Fairlie 2004; 2005), are based on estimations of earnings regressions, and employ panel data and fixed effect identification strategies. Both show some evidence of the claim that business ownership provides a route for economic advancement, balanced against opportunities in the wage/salary sector. ${ }^{4}$ Similarly, Holtz-Eakin et al. (2000) note that social climbing by dint of one's own business acumen, as personified by the successful protagonists of Horatio Alger's rags-to-riches novels, has a powerful hold on American society. They estimate a version of a Markov model by ordinary least squares, where the dependent variable is the percentile in year $t+1$, explained by the percentile in year $t$ and a number of other explanatory variables. In order to allow for non-linearities in the relationship between present and past positions, a quadratic specification is employed. They find that self-employment is beneficial for individuals starting out at

\footnotetext{
${ }^{4}$ However, there are differences between male and female groups, as the latter do not benefit from self-employment as business owners, according to Fairlie (2005).
} 
the low end of the earnings distribution, whereas those who started up near the top of the distribution experienced a loss, compared to the wage earners.

It should be noted that the present study focuses more on the upper part of the income distribution, unlike many other studies of business ownership. The main issue here is business ownership as a means of ascending to and staying in the upper reaches of the income distribution, given that the business owners face "privileges" in terms a tax system which facilitates, if not encourages, tax avoidance.

There are other closely related analyses of distributional effects of business ownership: for instance, Hamiliton (2000) discusses explanations to differences in earnings distributions for selfemployed workers and paid employees, whereas Jenkins (1995) and Parker (1999) employ population sub-group inequality decomposition methods when discussing the relationship between income inequality and self-employment.

\section{Some empirical preliminaries}

\subsection{Data}

Identifying owners of small businesses is a challenging task, as noted by, e.g., Plesko (1995), HoltzEakin (2000) and Parker (2004). The data on small businesses come in corporate and individual level versions. This is illustrated in Figure 1, where we show developments at the personal level, the upper panel for the period 1993-2003, and at the corporate level, the lower panel for the period 1995-2003. In the upper panel we divide the individuals in work into wage earners and self-employed, based on information in the Norwegian national accounts (Skoglund, 2001), derived originally from the labour force survey. Among what are defined as the self-employed, some people organize their activities as sole proprietorships and partnerships. The lower panel shows the corporate level data, based on income statistics for limited companies (Statistics Norway, 2008). Corporations are either closely held or widely held firms. A closely held firm is defined by active owners (working more than 300 hours annually) holding more than two thirds of the shares. However, active owners in closely held and widely held firms will normally be defined as wage earners if they work in the business they own and hence be included in the wage earner category in the upper panel. However, as this paper argues, the category "owners of small businesses" should include self-employed and active owners of closely held firms. Moreover, and this is a main point here, many active owners of widely held firms should be placed in the small business category. The idea finds empirical support in the number of business owners who re-classified their business for tax reasons during the nineties, taking the opportunity encouraged by the Norwegian dual income tax system to reclassify the business as a widely held firm 
(Thoresen and Alstadsæter, 2008). Descriptions in Figure 1 accord with this; we see a decrease in the number of self-employed, a stable number of closely held firms and a substantial increase in the number of widely held firms.

Figure 1. Number of wage earners and self-employed 1993-2003, number of widely held and closely held firms 1995-2005
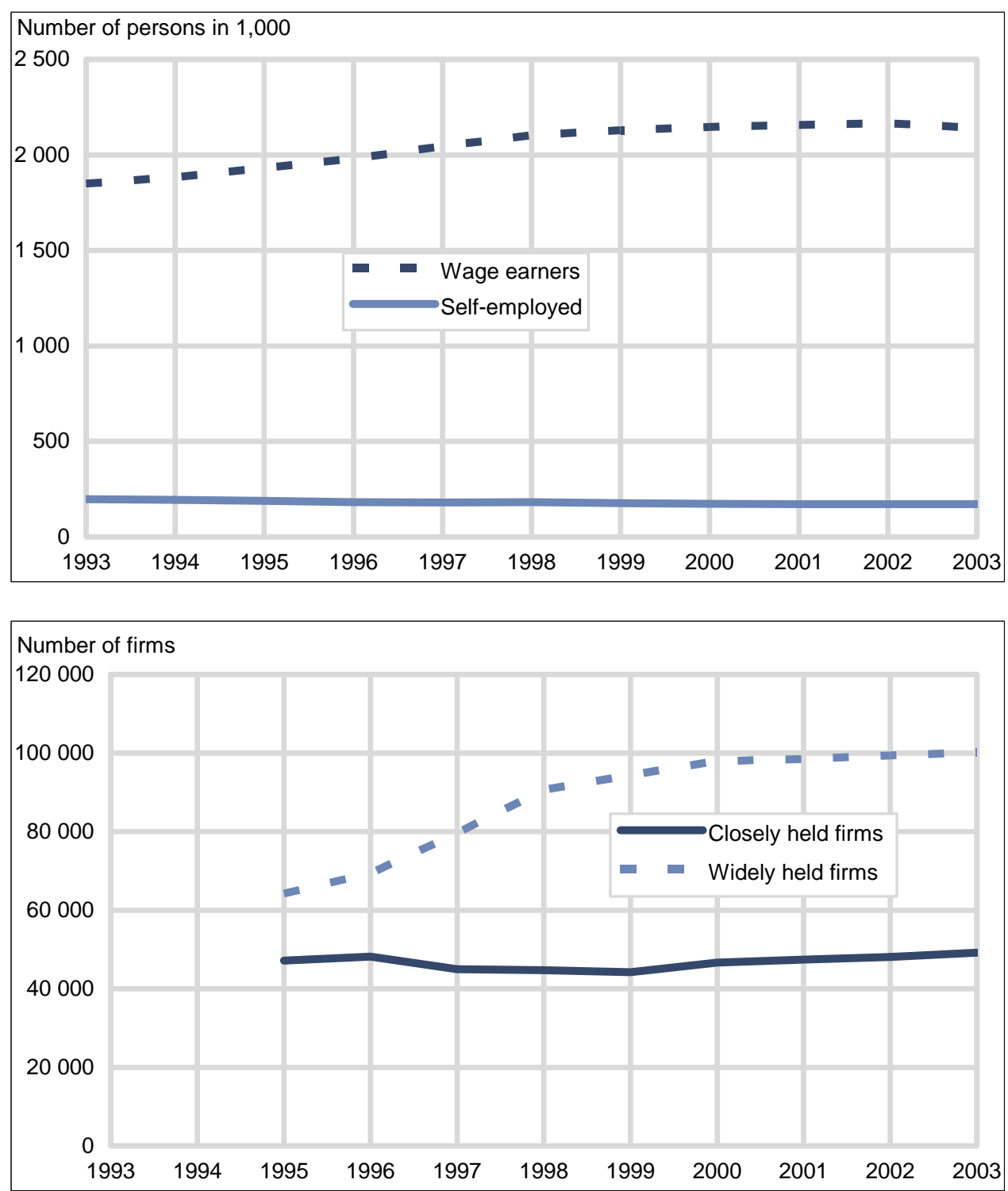

Sources: Labour force survey, Income statistics for limited companies

The data on which this study is mainly based are from the Income Statistics on Persons and Families, see Statistics Norway (2006a). These statistics hold register-based information on the whole population, based primarily on income tax returns filed with the Directorate of Taxes' Register of Personal Tax-Payers. Other sources provide many of the demographic variables. Thus, as these data 
cover the whole population, they are rich in information. 1993 was chosen as the first year of the analysis because that was when the register itself was established.

In terms of scope we restrict the analysis to individuals with a connection to the workforce; pensioners and students are therefore excluded. We did this by excluding all except prime aged individuals, i.e., persons aged 25-55 in the period 1993-2003, earning a wage or business income in excess of the Basic Pension Unit of the National Insurance Scheme in every year of the period. In 1993 the Basic Pension Unit was NOK 37,033 (USD 5,230), rising to NOK 55,964 (USD 7,900) in 2003. After these constraints, we were left with a sample of approximately 900,000 individuals, wage earners and self-employed. As data come from public records, the present analysis does not suffer from attrition problems, as frequently reported in other panel data analyses.

Farmers and fishermen are usually defined as self-employed. ${ }^{5}$ However, as Norwegian primary industries are heavily subsidized and regulated, we excluded these groups from the sample. Nor are they included in the categories "owners of small businesses" or "wage earners".

As already noted, there are three categories of small business owner: self-employed; owners of closely held corporations under the split-model; and owners of widely held corporations. The selfemployed are identified by reporting business income from self-employment (positive or negative). Owners of closely held corporations are recognized in that they report imputed labor income under the split model in combination with reporting wage income. ${ }^{6}$ The main problem, when addressing this issue empirically, is that it has previously been impossible to identify owners of small firms who run their business as a widely held firm. Income tax return data let us observe individuals who combine wage earning status with status as a recipient of dividends, but so far we have been unable to ascertain whether the wages and dividends come from the same firm. Obviously, this is essential for identifying owners of small businesses. However, the new Register of Shareholders has changed all this. By combining information from the Register of Shareholders and wage information from the End of the Year Certificate Register, which tells us which firm is paying the individual's wages, it is now possible to find wage earners who are simultaneously employees and major shareholders of the same firm. However, 2004 was the first year for which the Register of Shareholders issued data, so we rely on data from 2004 to establish end-of-period status only. As we have a longitudinal perspective in this analysis, we need to make assumptions about status in previous years. We do this as follows. We let information on status in 2004 determine status in 2003. If subjects, according to the data, were likely wage earners before 2003, we assume it holds true for the preceding years. If they are identified as self-employed or owners of a closely held corporation in preceding years, the business will likely have

\footnotetext{
${ }^{5}$ See Parker (2004) for more details on different definitions of firms.
} 
changed organizational classification in the period. By placing further constraints on the size of the firm and degree of ownership or control, we can begin to identify small business owners who run their businesses as widely held firms. ${ }^{7}$

Thus, in discussing the relationship between income mobility and small business ownership, the study deploys two definitions of the latter. The first is a narrow definition which includes the selfemployed and owners of closely held firms. The second is a wider definition which in addition to the categories just mentioned covers some owners of widely held firms. Table 1 presents the number of observations used in the present study, categorized into wage earners and the two definitions of small business owner. The wide definition gives us the figures for wage earners, as it places a number of "wage earners" in widely held firms in the business owner category. It shows that the wide definition increases the number of business owners substantially. As the years progress, the number of wage earners decreases and the number of owners of small businesses grows. However, behind this overall picture, individuals are switching occupations; an issue to which we return in Section 3.

Table 1. Number of observations, 1993-2003

\begin{tabular}{cccc}
\hline & $\begin{array}{c}\text { Wage earners (derived } \\
\text { by the wide def. of } \\
\text { small businesses) }\end{array}$ & $\begin{array}{c}\text { Owners of small } \\
\text { businesses, narrow } \\
\text { definition }\end{array}$ & $\begin{array}{c}\text { Owners of small } \\
\text { businesses, wide } \\
\text { definition }\end{array}$ \\
\hline 1993 & 769,088 & 102,178 & 128,428 \\
1994 & 767,575 & 103,601 & 129,941 \\
1995 & 765,279 & 106,604 & 132,237 \\
1996 & 765,935 & 105,246 & 131,581 \\
1997 & 765,951 & 105,456 & 131,565 \\
1998 & 764,122 & 106,603 & 133,394 \\
1999 & 764,437 & 105,892 & 133,079 \\
2000 & 763,222 & 107,104 & 134,294 \\
2001 & 762,137 & 108,736 & 135,379 \\
2002 & 762,869 & 107,911 & 134,647 \\
2003 & 764,341 & 106,196 & 133,175 \\
\hline
\end{tabular}

\subsection{Income inequality among business owners and wage earners: individual versus household data}

In most countries, income inequality is higher among the self-employed than among wage earners (Parker, 2004), and even though we focus on a broader group of business owners, we expect this to

\footnotetext{
${ }^{6}$ Some owners of closely held firms will not be identified as their income is too small to generate positive imputed labor income under the split model.

${ }^{7}$ This method also implies that some owners of closely held firms will be correctly categorized as business owners, i.e. those who do not report imputed labor income under the split model. They are few compared to the business owners involved in organizational shifts.
} 
hold true in the present case as well. Moreover, as income mobility can be studied at the individual and household level, we ask how far the results obtained from the use of the individual data replicate results based on household data.

There is little theoretical guidance with regard to explaining the forces underlying the wider income inequality found among the self-employed (Parker, 2004). It is generally accepted that incomes from business ownership are more uncertain than wages, but causal links between these factors and income inequality are hard to establish.

Figure 2 contains two panels; the upper panel shows changes in income inequality for business owners and wage earners based on individual income, and the lower panel for wage earners and self-employed based on household category. The household data are taken into account by aggregating income over all household members, dividing the sum by an equivalence scale to allow for economies of scale, ${ }^{8}$ and letting each household be represented with as many persons as there are household members. The allocation of households between income earners and self-employed is based on the status of the main income earner. The results presented on Figure 2 are reassuring with regard to both of the questions posed by the study. First, they confirm higher inequality among business owners than among wage earners, both at the individual and household level. Second, we see that the individual data basically describe the period 1993-2003 in the same manner as when the household is used as the unit of analysis. We also see (upper panel) that using the narrow or the wider definition of owners of businesses does have effect on year-specific inequality measures. The wider definition gives more income inequality by the end of the period, which we expected, given Thoresen and Alstadsæter’s (2008) finding that business owners shift organizational form to reduce the tax burden and increase post-tax income.

\footnotetext{
${ }^{8}$ The equivalence scale is defined as the square root of the number of household members, children included.
} 
Figure 2. Inequality of wage earners and self-employed 1993-2003, individual data and household data
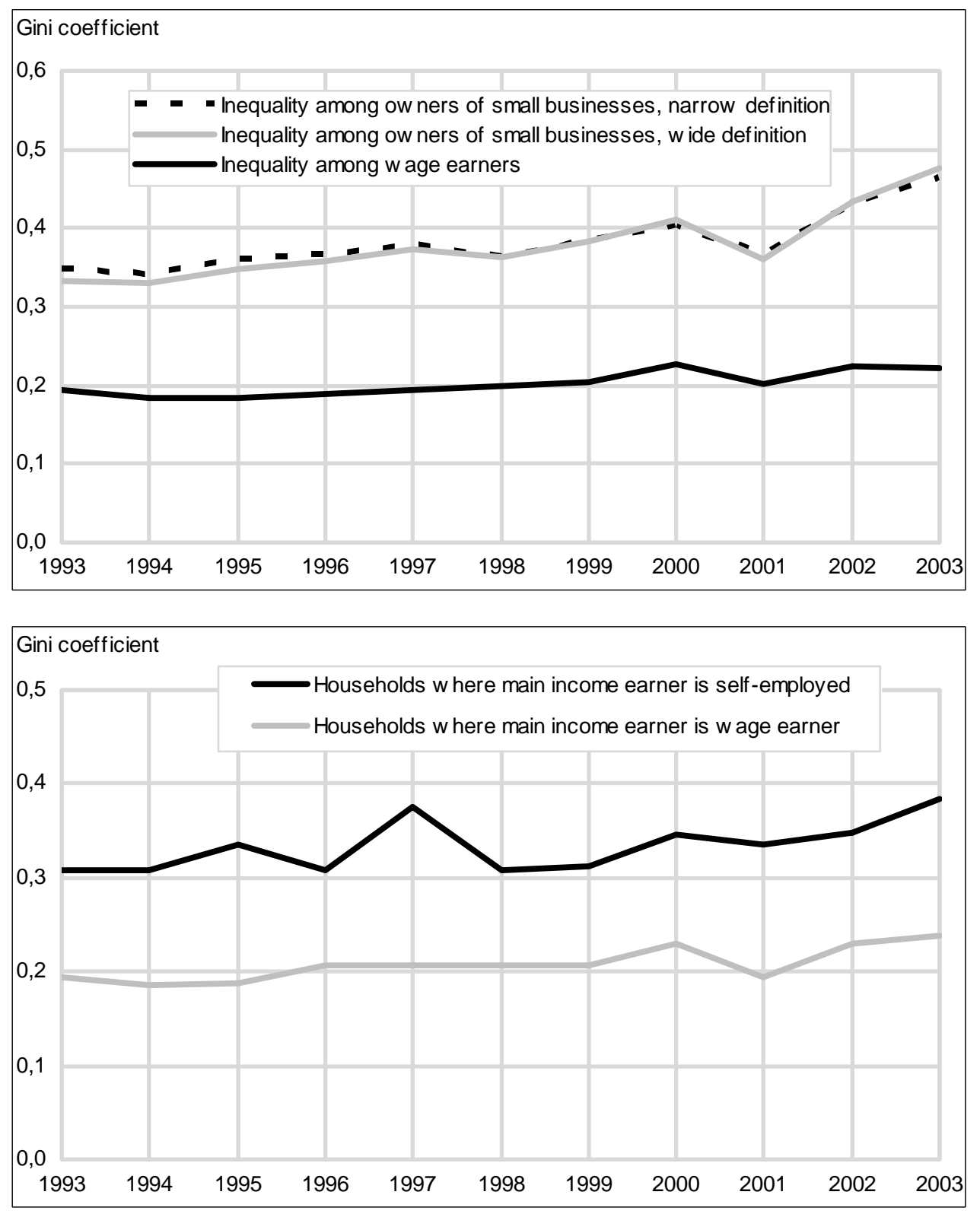

\subsection{The link between business ownership and mobility. Evidence from the transition matrices}

A transition matrix forms the natural starting point for studies of income mobility. In this section mobility evidence from transition matrices will be discussed, whereas the next section will look at the relationship between occupations (on varying definitions) and income mobility in terms of a dynamic process. 
However, let us first see how the owners of small businesses distribute on different quintiles in the period under consideration. Table 2 describes the location of wage earners and the owners of small businesses on the distribution scale of post-tax incomes on the two definitions of small business owner. Table 2 shows the distribution of wage earners and business owners in the overall distributions of post-tax income, but where percentage shares for each occupation group sum to 100 . The results of Table 2 reflect the wider dispersion of incomes among business owners. Whereas wage earners are more or less equally distributed on quintiles, owners of small businesses are much more likely to be found in quintiles 1 and 5. For instance, 25 percent of all owners of small businesses were in quintile 1 in 1993, according to the wide definition. It is also important to note how the wide definition increases the share of owners ending up in quintile 5, especially at the end of the period, which is in accordance with expectations. However, the difference is small.

Table 2. Distributions of wage earners and owners of small businesses, according to two definitions. Distributions on quintiles for each group, 1993-2003

\begin{tabular}{l|ccccc|ccccc|ccccc}
\hline & \multicolumn{5}{|c|}{ Wage earners } & \multicolumn{4}{|c|}{$\begin{array}{c}\text { Owners of small businesses, } \\
\text { narrow definition }\end{array}$} & \multicolumn{4}{c}{ Owners of small businesses, wide } \\
& \multicolumn{5}{|c}{} & \multicolumn{4}{|c}{ definition } \\
\hline Year & Q1 & Q2 & Q3 & Q4 & Q5 & Q1 & Q2 & Q3 & Q4 & Q5 & Q1 & Q2 & Q3 & Q4 & Q5 \\
\hline-93 & 19.1 & 21.0 & 21.2 & 20.7 & 18.0 & 28.6 & 13.8 & 12.1 & 14.5 & 31.0 & 25.1 & 13.8 & 13.1 & 15.8 & 32.1 \\
-94 & 19.1 & 21.1 & 21.2 & 20.7 & 17.9 & 29.2 & 13.2 & 11.9 & 14.5 & 31.2 & 25.6 & 13.3 & 12.8 & 15.8 & 32.6 \\
-95 & 18.9 & 21.2 & 21.3 & 20.7 & 17.8 & 30.2 & 12.9 & 11.6 & 14.5 & 30.8 & 26.5 & 12.9 & 12.3 & 15.7 & 32.6 \\
-96 & 18.9 & 21.2 & 21.3 & 20.7 & 17.9 & 30.3 & 13.2 & 12.0 & 14.5 & 30.0 & 26.3 & 13.0 & 12.6 & 15.8 & 32.4 \\
-97 & 18.9 & 21.2 & 21.3 & 20.7 & 17.9 & 30.3 & 13.5 & 12.0 & 14.8 & 29.5 & 26.2 & 13.1 & 12.5 & 15.9 & 32.3 \\
-98 & 19.1 & 21.3 & 21.3 & 20.6 & 17.8 & 28.9 & 13.2 & 12.4 & 15.6 & 30.0 & 25.1 & 12.7 & 12.8 & 16.7 & 32.8 \\
-99 & 19.0 & 21.3 & 21.3 & 20.6 & 17.9 & 29.9 & 12.9 & 12.3 & 15.6 & 29.3 & 25.9 & 12.5 & 12.7 & 16.6 & 32.3 \\
-00 & 19.3 & 21.4 & 21.3 & 20.5 & 17.6 & 27.9 & 12.5 & 12.6 & 16.3 & 30.7 & 24.2 & 12.1 & 12.8 & 17.1 & 33.8 \\
-01 & 19.1 & 21.4 & 21.3 & 20.5 & 17.7 & 28.1 & 12.5 & 12.4 & 16.1 & 30.8 & 24.9 & 12.3 & 12.8 & 17.2 & 32.8 \\
-02 & 19.3 & 21.4 & 21.2 & 20.5 & 17.5 & 27.0 & 12.6 & 12.7 & 16.3 & 31.5 & 23.8 & 12.3 & 12.9 & 16.9 & 34.0 \\
-03 & 18.6 & 21.4 & 21.4 & 20.8 & 17.8 & 32.1 & 12.2 & 11.9 & 14.3 & 29.5 & 27.9 & 11.9 & 12.1 & 15.1 & 32.9 \\
\hline
\end{tabular}

Another way of addressing the distribution of small business owners across quintiles is to calculate the proportion of owners in different quintiles. This is done in Table 3, where we compare the narrow and the wider definitions. In contrast to Table 2, the figures in Table 2 reflect the size of the business owner sector relative to the wage earner sector across quintiles. For instance, in 1993, in the lowest quintile of the income hierarchy, 16.3 percent were owners of small businesses, whereas the corresponding estimate for the 20 percent richest was 17.6 percent. 
Table 3. Percentage share of owners of small businesses in quintiles (according to two definitions), 1993-2003

\begin{tabular}{l|ccccc|ccccc}
\hline & \multicolumn{3}{|c|}{ Owners of small businesses, narrow } & \multicolumn{3}{c}{ Owners of small businesses, wide definition } \\
\hline Year & Q1 & Q2 & Q3 & Q4 & Q5 & Q1 & Q2 & Q3 & Q4 & Q5 \\
\hline-93 & 16.3 & 7.9 & 6.9 & 8.3 & 17.6 & 18.0 & 9.9 & 9.4 & 11.3 & 23.0 \\
-94 & 16.9 & 7.6 & 6.9 & 8.4 & 18.0 & 18.5 & 9.6 & 9.2 & 11.4 & 23.6 \\
-95 & 18.0 & 7.7 & 6.9 & 8.6 & 18.3 & 19.5 & 9.5 & 9.1 & 11.5 & 24.0 \\
-96 & 17.8 & 7.7 & 7.0 & 8.5 & 17.6 & 19.3 & 9.5 & 9.2 & 11.5 & 23.8 \\
-97 & 17.8 & 7.9 & 7.0 & 8.7 & 17.4 & 19.2 & 9.6 & 9.1 & 11.7 & 23.7 \\
-98 & 17.1 & 7.8 & 7.4 & 9.2 & 17.8 & 18.6 & 9.5 & 9.5 & 12.4 & 24.3 \\
-99 & 17.7 & 7.6 & 7.3 & 9.2 & 17.3 & 19.2 & 9.3 & 9.4 & 12.3 & 24.0 \\
-00 & 16.6 & 7.5 & 7.5 & 9.7 & 18.3 & 18.1 & 9.1 & 9.6 & 12.8 & 25.3 \\
-01 & 17.0 & 7.6 & 7.5 & 9.8 & 18.7 & 18.7 & 9.3 & 9.7 & 13.0 & 24.8 \\
-02 & 16.2 & 7.5 & 7.6 & 9.8 & 18.9 & 17.9 & 9.2 & 9.7 & 12.7 & 25.5 \\
-03 & 19.0 & 7.2 & 7.0 & 8.5 & 17.4 & 20.7 & 9.0 & 9.0 & 11.2 & 24.4 \\
\hline
\end{tabular}

Turning to mobility tables, we can identify how the same individuals move from one point in time to the next, the main hypotheses being that business ownership covaries with upward movements along the income distribution hierarchy and secures positions at the high end of the scale. In this perspective, the income gains from business ownership may follow from different combinations of connections to business ownership over time: e.g., individuals are business owners for the whole period, or they shift from wage earner to business owner, or, not at least given the issue raised in this paper, they may be involved in organizational shifts as a business owner.

The timeframe of the analysis is important. For instance, it is well known that mobility patterns depend on the length of the transition period (Atkinson et al., 1992; Holtz-Eakin et al., 2000). The period is important both with respect to the measurement of income, occupational categorization and measurement of shift. Here the main focus is on year-on-year transitions, but we also give the results for income measures based on aggregations for several calendar years. Moreover, as mobility patterns may change during the period to which the data refer (1993-2003), separate estimates for transitions early and late in the period will be presented. However, the main focus here is on mobility according to the two definitions of business owner, the narrow and the wide definition. 
Table 4. Percentage of owners of small firms for combinations of period $t-1$ and period $t$ quintiles. Yearly transitions, 1993-1994, 1997-1998, and 2002-2003 for two definitions of business owners.

\begin{tabular}{|c|c|c|c|c|c|c|c|c|c|c|c|c|c|}
\hline \multicolumn{14}{|c|}{ Transitions 1993-1994, owners of small businesses in both periods } \\
\hline \multicolumn{7}{|c|}{$\begin{array}{l}\text { Narrow def.: self-employed, owners of closely } \\
\text { held firms }(87,666 \text { obs) }\end{array}$} & \multicolumn{7}{|c|}{$\begin{array}{l}\text { Wide def.: self-employed, owners of closely held } \\
\text { and widely held firms (116,417 obs) }\end{array}$} \\
\hline \multirow{2}{*}{$\begin{array}{l}\text { From } \\
\text { quintile }\end{array}$} & \multicolumn{5}{|c|}{ To quintile } & \multirow[b]{2}{*}{ Total } & \multirow{2}{*}{$\begin{array}{l}\text { From } \\
\text { quintile }\end{array}$} & \multicolumn{5}{|c|}{ To quintile } & \multirow[b]{2}{*}{ Total } \\
\hline & 1 & 2 & 3 & 4 & 5 & & & 1 & 2 & 3 & 4 & 5 & \\
\hline 1 & 21.6 & 3.6 & 1.6 & 1.0 & 1.0 & 28.8 & 1 & 18.0 & 3.3 & 1.4 & 1.0 & 0.9 & 24.6 \\
\hline 2 & 4.7 & 4.5 & 2.5 & 1.4 & 0.9 & 14.0 & 2 & 4.1 & 5.0 & 2.6 & 1.4 & 0.8 & 13.9 \\
\hline 3 & 1.7 & 2.6 & 3.5 & 2.6 & 1.5 & 11.9 & 3 & 1.5 & 2.8 & 4.5 & 2.9 & 1.4 & 13.0 \\
\hline 4 & 1.0 & 1.5 & 2.8 & 5.1 & 3.9 & 14.3 & 4 & 0.9 & 1.4 & 3.0 & 6.5 & 4.1 & 15.8 \\
\hline 5 & 0.8 & 0.8 & 1.3 & 4.0 & 24.2 & 31.1 & 5 & 0.7 & 0.7 & 1.2 & 4.0 & 26.1 & 32.7 \\
\hline Total & 29.8 & 13.0 & 11.6 & 14.2 & 31.4 & 100.0 & Total & 25.3 & 13.1 & 12.7 & 15.7 & 33.2 & 100.0 \\
\hline
\end{tabular}

Transitions 1997-1998, owners of small businesses in both periods

\begin{tabular}{|c|c|c|c|c|c|c|c|c|c|c|c|c|c|}
\hline \multicolumn{7}{|c|}{$\begin{array}{c}\text { Narrow def.: self-employed, owners of closely } \\
\text { held firms ( } 89,754 \text { obs) }\end{array}$} & \multicolumn{7}{|c|}{$\begin{array}{l}\text { Wide def.: self-employed, owners of closely held } \\
\text { and widely held firms (118,996 obs) }\end{array}$} \\
\hline \multirow{2}{*}{$\begin{array}{l}\text { From } \\
\text { quintile }\end{array}$} & \multicolumn{5}{|c|}{ To quintile } & \multirow[b]{2}{*}{ Total } & \multirow{2}{*}{$\begin{array}{l}\text { From } \\
\text { quintile }\end{array}$} & \multicolumn{5}{|c|}{ To quintile } & \multirow[b]{2}{*}{ Total } \\
\hline & 1 & 2 & 3 & 4 & 5 & & & 1 & 2 & 3 & 4 & 5 & \\
\hline 1 & 22.9 & 4.3 & 2.0 & 1.3 & 0.9 & 31.4 & 1 & 18.8 & 3.7 & 1.7 & 1.1 & 0.8 & 24.6 \\
\hline 2 & 3.7 & 4.4 & 2.7 & 1.8 & 0.9 & 13.5 & 2 & 3.3 & 4.6 & 2.7 & 1.6 & 0.8 & 13.9 \\
\hline 3 & 1.5 & 2.5 & 3.6 & 2.9 & 1.3 & 11.7 & 3 & 1.3 & 2.4 & 4.2 & 3.1 & 1.3 & 13.0 \\
\hline 4 & 0.9 & 1.3 & 2.6 & 5.7 & 4.0 & 14.4 & 4 & 0.8 & 1.2 & 2.8 & 6.8 & 4.3 & 15.8 \\
\hline 5 & 0.9 & 0.7 & 1.1 & 3.5 & 22.8 & 29.0 & 5 & 0.9 & 0.7 & 1.2 & 3.9 & 26.2 & 32.7 \\
\hline Total & 29.9 & 13.1 & 12.0 & 15.1 & 29.9 & 100.0 & Total & 25.1 & 12.6 & 12.5 & 16.4 & 33.4 & 100.0 \\
\hline
\end{tabular}

Transitions 2002-2003, owners of small businesses in both periods

\begin{tabular}{|c|c|c|c|c|c|c|c|c|c|c|c|c|c|}
\hline \multicolumn{7}{|c|}{$\begin{array}{l}\text { Narrow def.: self-employed, owners of closely } \\
\text { held firms (90,957 obs) }\end{array}$} & \multicolumn{7}{|c|}{$\begin{array}{l}\text { Wide def.: self-employed, owners of closely held } \\
\text { and widely held firms (121,041 obs) }\end{array}$} \\
\hline \multirow{2}{*}{$\begin{array}{l}\text { From } \\
\text { quintile }\end{array}$} & \multicolumn{5}{|c|}{ To quintile } & \multirow[b]{2}{*}{ Total } & \multirow{2}{*}{$\begin{array}{l}\text { From } \\
\text { quintile }\end{array}$} & \multicolumn{5}{|c|}{ To quintile } & \multirow[b]{2}{*}{ Total } \\
\hline & 1 & 2 & 3 & 4 & 5 & & & 1 & 2 & 3 & 4 & 5 & \\
\hline 1 & 22.0 & 2.9 & 1.3 & 0.7 & 1.0 & 27.8 & 1 & 18.1 & 2.6 & 1.2 & 0.7 & 1.1 & 23.7 \\
\hline 2 & 5.2 & 3.6 & 2.0 & 1.0 & 0.6 & 12.4 & 2 & 4.4 & 3.8 & 2.1 & 1.0 & 0.7 & 12.1 \\
\hline 3 & 3.1 & 2.5 & 3.5 & 2.2 & 1.0 & 12.4 & 3 & 2.6 & 2.4 & 3.9 & 2.4 & 1.3 & 12.6 \\
\hline 4 & 2.1 & 2.0 & 3.0 & 5.7 & 3.1 & 15.9 & 4 & 1.8 & 1.8 & 3.0 & 6.3 & 3.8 & 16.7 \\
\hline 5 & 1.5 & 1.1 & 1.6 & 4.1 & 23.2 & 31.5 & 5 & 1.4 & 1.0 & 1.6 & 4.3 & 26.5 & 34.9 \\
\hline Total & 33.8 & 12.1 & 11.5 & 13.7 & 28.9 & 100.0 & Total & 28.3 & 11.7 & 11.8 & 14.8 & 33.4 & 100.0 \\
\hline
\end{tabular}


Let us first address information on yearly transitions for owners of small business in period $t$ 1 and period $t$. Table 4 presents mobility tables, based on quintiles, for three periods, 1993-1994, 1997-1998, and 2002-2003, and for the two definitions. Results are presented in terms of (unconditional) percentages in each cell, showing the percentage of owners of small businesses combining being in quintile $r$ in period $t-1$ and quintile $s$ in period $t$. For instance, Table 4 shows that of all the owners of small businesses, according to the narrow definition, 21.6 of them were in quintile 1 both at time $t$ - 1 and at time $t$.

Upward mobility will be reflected by a larger percentage in higher quintiles in period $t$, compared to period $t$ - 1 , see Table 4 . We also expect the wider definition to show higher upward mobility than the narrow definition, probably towards the end of the period, i.e., 1997-1998 and 20022003 compared to 1993-94.

Table 4 does not indicate substantial upward mobility of owners of small businesses. The share of owners of small firms in quintile 5 in year $t-1$ is little different from the share in year $t$; compare column totals and row totals for quintile 5 . As expected, the wider definition results in better performance for owners of small businesses, but we do not observe increased upwards movement in the period. In fact, there were fewer owners in quintile 5 in 2003 than in 2002. If we extend the income measurement period, i.e., transitions when rankings (in both $t-1$ and $t$ ) are determined by aggregate post-tax income for several years (aggregate incomes for period 1993-1998 and period 1998-2003), the pattern (not shown) is basically the same as seen in Table 4. Similar results are also seen for a longer transition period, e.g., comparing transitions between $1993(t-1)$ and $2003(t)$.

Such tables can straightforwardly be turned into indices of overall mobility. Let us therefore first consider what estimates of indices of mobility say about overall mobility of business owners and wage earners. Table 5 presents estimates of overall mobility over the three periods for the three subgroups, for two measures of income mobility. The two mobility measures are defined in terms of conditional transition probabilities, $p_{j k}$, the probability that an individual moves to class $k$ given that he/she was initially in class $j$. The mapping of the probabilities into indices of mobility follows suggestions by Prais (1955)/Shorrocks (1978) (PS) and Bartholomew (1982) (B), seen as

$$
P S=\frac{m-\sum_{j=1}^{m} p_{j j}}{m-1}
$$

and

$$
B=\frac{1}{m-1} \sum_{j=1}^{m} \sum_{k=1}^{m} \pi_{j} p_{j k}|j-k|
$$


respectively, where $m$ is the number of income classes and $\pi_{j}$ is the initial income distribution. $P S$ measures the average probability across all income classes that a person leaves the initial class in the succeeding period, whereas $B$ measures the average number of income classes crossed by all individuals; see e.g., Formby et al. (2004) for more details.

The results of Table 5 confirm the substantially higher income mobility of small business owners than wage earners. Both measures of income mobility show this across all three time periods. ${ }^{9}$

Table 4. Income mobility of wage earners and owners of small businesses, 1993-1994, 19971998, and 2002-2003

\begin{tabular}{llccc}
\hline & & \multicolumn{3}{c}{ Occupational status } \\
\cline { 3 - 5 } Period & $\begin{array}{l}\text { Mobility } \\
\text { indices }\end{array}$ & Wage earner & $\begin{array}{c}\text { Owners of small } \\
\text { businesses, narrow } \\
\text { definition }\end{array}$ & $\begin{array}{c}\text { Owners of small } \\
\text { businesses, wide } \\
\text { definition }\end{array}$ \\
\hline \multirow{2}{*}{$1993-94$} & $P S$ & 0.423 & 0.538 & 0.516 \\
& $B$ & 0.415 & 0.556 & 0.536 \\
\hline \multirow{2}{*}{$1997-98$} & $P S$ & 0.408 & 0.534 & 0.516 \\
& $B$ & 0.390 & 0.554 & 0.537 \\
\hline \multirow{2}{*}{$2002-03$} & $P S$ & 0.369 & 0.558 & 0.553 \\
& $B$ & 0.357 & 0.594 & 0.587 \\
\hline
\end{tabular}

Improvements in the relative positions of owners of small firms may also be reflected by this occupational group's overrepresentation at the high end of the income distribution: firm owners are immobile at the top of the income distribution. To test this hypothesis, we compared results from Table 4 to similar mobility tables for wage earners. The result for wage earners is presented in Table 6 . The relevant comparison is the probability of staying in quintile 5 (quintile 5 both at $t-1$ and at $t$ ) over the probability of being in quintile 5 in period $t$ - 1 for owners of small businesses (Table 4 ) and wage earners (Table 6). Both tables generate probabilities for staying in quintile 5 around 0.8 . In other words, staying rich does not appear to be affected by business ownership, according to the mobility tables.

\footnotetext{
${ }^{9}$ There are probably effects from ageing in the panel, which may account for some of the reduction in mobility for wage earners.
} 
Table 6. Percentage of wage earners for combinations of period $t-1$ and period $t$ quintiles. Yearly transitions, 1993-1994 and 2002-2003.

\begin{tabular}{|c|c|c|c|c|c|c|c|c|c|c|c|c|c|}
\hline \multicolumn{7}{|c|}{ Wage earner mobility, 1993-1994 (755,564 obs) } & \multicolumn{7}{|c|}{ Wage earner mobility, 2002-2003 (750,735 obs) } \\
\hline \multirow{2}{*}{$\begin{array}{l}\text { From } \\
\text { quintile }\end{array}$} & \multicolumn{5}{|c|}{ To quintile } & \multirow[b]{2}{*}{ Total } & \multirow{2}{*}{$\begin{array}{l}\text { From } \\
\text { quintile }\end{array}$} & \multicolumn{5}{|c|}{ To quintile } & \multirow[b]{2}{*}{ Total } \\
\hline & 1 & 2 & 3 & 4 & 5 & & & 1 & 2 & 3 & 4 & 5 & \\
\hline 1 & 14.1 & 3.2 & 1.0 & 0.5 & 0.2 & 19.0 & 1 & 14.9 & 3.5 & 0.5 & 0.2 & 0.2 & 19.2 \\
\hline 2 & 3.8 & 12.7 & 3.5 & 0.8 & 0.2 & 21.1 & 2 & 2.6 & 14.1 & 4.1 & 0.6 & 0.1 & 21.5 \\
\hline 3 & 0.6 & 4.4 & 12.2 & 3.6 & 0.4 & 21.3 & 3 & 0.5 & 3.2 & 13.3 & 4.0 & 0.3 & 21.3 \\
\hline 4 & 0.3 & 0.7 & 4.2 & 13.1 & 2.6 & 20.8 & 4 & 0.3 & 0.6 & 3.3 & 13.9 & 2.5 & 20.6 \\
\hline 5 & 0.1 & 0.1 & 0.3 & 2.9 & 14.3 & 17.9 & 5 & 0.2 & 0.2 & 0.3 & 2.2 & 14.5 & 17.4 \\
\hline Total & 18.9 & 21.2 & 21.3 & 20.8 & 17.8 & 100.0 & Total & 18.4 & 21.5 & 21.5 & 20.9 & 17.7 & 100.0 \\
\hline
\end{tabular}

The mobility matrices presented in Table 4 and Table 6 are based on individuals whose occupational status remains unchanged throughout the period. It is interesting to see to whether occupational shifts do in fact covary with upward movements. In Table 7 mobility matrices for two types of change from period $t$ to period $t-1$ are presented: shift from wage earner to small business owner and from self-employment or closely held firm to owner of widely held firm. The latter shift captures the effect of changing the organizational form of the business, whereas the former captures the more traditional effect of leaving employment to run a business. Ideally, one should also explore the shift from being a (real) wage earner to running a business through a widely held firm. However, our data are not perfect, and we base our identification of owners of widely held firms on information from the end of the period; categorizations in preceding years are based on imputations (see Section 3.1).

The mobility matrices of Table 7 indicate a benefit from shifting occupation from wage earner to small business owner in terms of position in the income hierarchy; see the left hand side of the table. The proportion of "shifters" in quintile 5 at time $t$, for instance, is larger than the proportion in quintile 5 in period $t-1$ for all three transitions presented in Table 7.

With respect to the organizational shift of owners of small businesses (from self-employment and closely held firm to widely held firm), these individuals, crucially, are overrepresented in quintile 5 both before and after the organizational shift (see the right hand side of Table 6), and income positions are less influenced by the transition; if anything, we can observe a small decrease in proportions in quintile 5 (especially for the 1998-1999 transitions). 
Table 7. Shifts from wage earner to owner of small business and shift from self-employment and closely held firm to widely held firm. Percentage of "shifters" for combinations of period $t-1$ and period $t$ quintiles. Yearly transitions, 1993-1994, 1997-1998, and 20022003.

\begin{tabular}{|c|c|c|c|c|c|c|c|c|c|c|c|c|c|}
\hline \multicolumn{14}{|c|}{ Transitions 1993-1994 } \\
\hline \multicolumn{7}{|c|}{$\begin{array}{l}\text { From wage earner to owner of small business } \\
\qquad(13,524 \text { obs })\end{array}$} & \multicolumn{7}{|c|}{$\begin{array}{l}\text { From self-employment and closely held firm to } \\
\text { widely held firm (2,501 obs) }\end{array}$} \\
\hline \multirow{2}{*}{$\begin{array}{l}\text { From } \\
\text { quintile }\end{array}$} & \multicolumn{5}{|c|}{ To quintile } & \multirow[b]{2}{*}{ Total } & \multirow{2}{*}{$\begin{array}{l}\text { From } \\
\text { quintile }\end{array}$} & \multicolumn{5}{|c|}{ To quintile } & \multirow[b]{2}{*}{ Total } \\
\hline & 1 & 2 & 3 & 4 & 5 & & & 1 & 2 & 3 & 4 & 5 & \\
\hline 1 & 19.5 & 4.6 & 2.1 & 1.7 & 1.7 & 29.5 & 1 & 6.9 & 2.8 & 1.2 & 1.1 & 1.6 & 13.6 \\
\hline 2 & 4.9 & 5.5 & 3.2 & 2.0 & 1.4 & 17.1 & 2 & 1.8 & 3.8 & 1.8 & 1.7 & 0.6 & 9.7 \\
\hline 3 & 2.1 & 2.8 & 4.9 & 3.4 & 1.7 & 14.8 & 3 & 1.1 & 2.8 & 4.2 & 3.2 & 1.6 & 12.8 \\
\hline 4 & 0.9 & 1.3 & 2.6 & 6.5 & 4.4 & 15.7 & 4 & 0.8 & 1.0 & 2.7 & 7.3 & 5.2 & 17.0 \\
\hline 5 & 0.7 & 0.5 & 0.9 & 2.8 & 18.0 & 22.9 & 5 & 1.3 & 1.2 & 2.2 & 4.8 & 37.4 & 46.9 \\
\hline Total & 28.1 & 14.7 & 13.7 & 16.4 & 27.2 & 100.0 & Total & 11.8 & 11.6 & 12.2 & 18.0 & 46.5 & 100.0 \\
\hline
\end{tabular}

Transitions 1998-1999

\begin{tabular}{|c|c|c|c|c|c|c|c|c|c|c|c|c|c|}
\hline \multicolumn{7}{|c|}{$\begin{array}{l}\text { From wage earner to owner of small business } \\
\qquad(14,398 \text { obs })\end{array}$} & \multicolumn{7}{|c|}{$\begin{array}{l}\text { From self-employment and closely held firm to } \\
\text { widely held firm (3,133 obs) }\end{array}$} \\
\hline \multirow{2}{*}{$\begin{array}{l}\text { From } \\
\text { quintile }\end{array}$} & \multicolumn{5}{|c|}{ To quintile } & \multirow[b]{2}{*}{ Total } & \multirow{2}{*}{$\begin{array}{l}\text { From } \\
\text { quintile }\end{array}$} & \multicolumn{5}{|c|}{ To quintile } & \multirow[b]{2}{*}{ Total } \\
\hline & 1 & 2 & 3 & 4 & 5 & & & 1 & 2 & 3 & 4 & 5 & \\
\hline 1 & 17.4 & 4.2 & 2.3 & 1.3 & 1.1 & 26.2 & 1 & 4.6 & 1.7 & 1.1 & 1.2 & 1.1 & 9.6 \\
\hline 2 & 4.1 & 5.6 & 3.3 & 2.0 & 1.1 & 16.1 & 2 & 1.6 & 2.8 & 1.9 & 1.3 & 0.9 & 8.5 \\
\hline 3 & 1.8 & 2.4 & 5.6 & 4.0 & 1.5 & 15.3 & 3 & 1.2 & 1.9 & 2.8 & 2.6 & 1.6 & 10.1 \\
\hline 4 & 1.0 & 1.1 & 3.1 & 8.4 & 4.5 & 18.1 & 4 & 0.8 & 1.3 & 2.4 & 7.0 & 5.3 & 16.8 \\
\hline 5 & 0.9 & 0.4 & 0.8 & 2.8 & 19.4 & 24.3 & 5 & 2.7 & 1.5 & 2.8 & 7.1 & 40.9 & 55.0 \\
\hline Total & 25.2 & 13.7 & 15.2 & 18.5 & 27.5 & 100.0 & Total & 10.9 & 9.2 & 11.1 & 19.2 & 49.7 & 100.0 \\
\hline
\end{tabular}

Transitions 2002-2003

\begin{tabular}{|c|c|c|c|c|c|c|c|c|c|c|c|c|c|}
\hline \multicolumn{7}{|c|}{$\begin{array}{l}\text { From wage earner to owner of small business } \\
\qquad(12,134 \text { obs })\end{array}$} & \multicolumn{7}{|c|}{$\begin{array}{l}\text { From self-employment and closely held firm to } \\
\text { widely held firm (3,348 obs) }\end{array}$} \\
\hline \multirow{2}{*}{$\begin{array}{l}\text { From } \\
\text { quintile }\end{array}$} & \multicolumn{5}{|c|}{ To quintile } & \multirow[b]{2}{*}{ Total } & \multirow{2}{*}{$\begin{array}{l}\text { From } \\
\text { quintile }\end{array}$} & \multicolumn{5}{|c|}{ To quintile } & \multirow[b]{2}{*}{ Total } \\
\hline & 1 & 2 & 3 & 4 & 5 & & & & & & & & \\
\hline 1 & 15.9 & 3.9 & 1.9 & 1.3 & 1.3 & 24.3 & 1 & 6.2 & 2.3 & 1.1 & 1.2 & 2.1 & 12.9 \\
\hline 2 & 4.0 & 5.2 & 3.5 & 1.8 & 0.9 & 15.4 & 2 & 1.8 & 3.3 & 2.2 & 1.0 & 1.3 & 9.5 \\
\hline 3 & 1.9 & 2.6 & 6.0 & 4.5 & 1.6 & 16.6 & 3 & 1.4 & 1.6 & 3.3 & 2.3 & 2.1 & 10.7 \\
\hline 4 & 1.6 & 1.5 & 2.7 & 8.0 & 4.8 & 18.5 & 4 & 1.1 & 1.3 & 2.5 & 5.4 & 5.2 & 15.5 \\
\hline 5 & 1.2 & 0.6 & 0.9 & 3.0 & 19.5 & 25.2 & 5 & 2.5 & 1.5 & 2.6 & 6.7 & 38.1 & 51.4 \\
\hline Total & 24.6 & 13.8 & 15.0 & 18.6 & 28.0 & 100.0 & Total & 13.1 & 9.9 & 11.7 & 16.6 & 48.7 & 100.0 \\
\hline
\end{tabular}


This latter result does not coincide with Thoresen and Alstadsæter’s (2008), referred to earlier, who found that business owners benefitted from organizational moves. Therefore, in order to assess the effect of employing income measures for longer time periods, which would align the present approach with that followed by Thoresen and Alstadsæter (2008), incomes are aggregated over fiveyear periods (letting occupation of the last year of each period define occupational categories). ${ }^{10}$ As shown in Table 8, organizational shifts now go together with upward movement in income rankings for five-year income measures. There may be various explanations for the dependency on the timeframe. The five-year specification, compared to the calendar year approach, captures lagged effects of organizational shifts. "Smoothing” of incomes over time may also affect business owners and wage earners differently, given the wider income variation among the former group (as seen in Table 3). Five-year aggregations may therefore moderate the effect of one or two less profitable years. We return to this periodization issue in the next section.

Table 8. Shifts from wage earner to owner of small business and shift from self-employment and closely held firm to widely held firm. Percentage of "shifters" for combinations of period $t-1$ and period $t$ quintiles. Transitions between five-year periods, 1993-1998 and 1998-2003.

\begin{tabular}{|c|c|c|c|c|c|c|c|c|c|c|c|c|c|}
\hline \multicolumn{7}{|c|}{$\begin{array}{l}\text { From wage earner to owner of small business } \\
\qquad(29,468 \text { obs })\end{array}$} & \multicolumn{7}{|c|}{$\begin{array}{l}\text { From self-employment and closely held firm to } \\
\text { widely held firm (5,878 obs) }\end{array}$} \\
\hline \multirow{2}{*}{$\begin{array}{l}\text { From } \\
\text { quintile }\end{array}$} & \multicolumn{5}{|c|}{ To quintile } & \multirow[b]{2}{*}{ Total } & \multirow{2}{*}{$\begin{array}{l}\text { From } \\
\text { quintile }\end{array}$} & \multicolumn{5}{|c|}{ To quintile } & \multirow[b]{2}{*}{ Total } \\
\hline & 1 & 2 & 3 & 4 & 5 & & & 1 & 2 & 3 & 4 & 5 & \\
\hline 1 & 13.9 & 3.4 & 1.5 & 0.7 & 0.6 & 20.1 & 1 & 6.6 & 2.8 & 1.9 & 1.2 & 1.8 & 14.3 \\
\hline 2 & 5.2 & 5.9 & 3.7 & 1.5 & 0.6 & 16.9 & 2 & 1.5 & 3.1 & 2.3 & 1.9 & 1.8 & 10.5 \\
\hline 3 & 2.4 & 4.0 & 5.9 & 4.5 & 1.3 & 18.1 & 3 & 0.6 & 1.4 & 3.1 & 3.1 & 2.7 & 11.0 \\
\hline 4 & 1.1 & 2.0 & 4.2 & 8.5 & 4.3 & 20.2 & 4 & 0.4 & 1.0 & 2.4 & 5.7 & 6.3 & 15.7 \\
\hline 5 & 0.3 & 0.6 & 1.0 & 4.0 & 18.9 & 24.8 & 5 & 0.3 & 0.6 & 1.3 & 5.5 & 40.7 & 48.4 \\
\hline Total & 22.8 & 15.9 & 16.3 & 19.2 & 25.7 & 100.0 & Total & 9.3 & 9.0 & 11.0 & 17.4 & 53.3 & 100.0 \\
\hline
\end{tabular}

\section{Further description of the correlation between business ownership and income movements}

\subsection{Specification of a transition equation}

The relationship between business ownership and position in the income hierarchy is further explored by a multivariate approach. The main advantage of a multivariate approach is that other observed

\footnotetext{
${ }^{10}$ The empirical approach in Thoresen and Alstadsæter (2008) is also based on aggregated incomes, but not the same aggregation as used here.
} 
influences can be controlled for when establishing a relationship between business ownership and income movement. Moreover, the panel data that are available for this study are not only useful as information on the movement of the same individuals over time, they help us address the effect of unobserved factors. In the following we estimate conditional equations, dependent on statuses in period $t-1$ and $t$, to assess the correlation between small business ownership, upward income mobility and high income persistence, when other observable and unobservable effects are addressed.

Before presenting the multivariate approach, we should note the emphasis here on noncausal interpretation of results. Owners of small businesses obviously self-select into the group, so that interpreting the results in terms of causal effects require methods that control for group allocation mechanisms. The main objective of the present study is to describe the achievements of owners of small businesses during a period with a dual income tax system in place, and not for a randomly selected person choosing business ownership. This is in accordance with assumptions implicitly or explicitly made by other studies closely related to the present study; see the review of literature in Section 2.

We address multivariate evidence through estimations of transition rates, which is a logical extension of the mobility matrices approach seen in the previous section. In the following, the approach is presented with reference to the relationship between business ownership and upward movement, but the same type of approach may be used for the analysis of high-income persistence.

The latent probability for individual $i$ belonging to state "non-rich" at time $t-1, y_{i t-1}^{*}$, can be seen as depending on a vector of explanatory variables, $x_{i t-1}$, and individual effect $\alpha_{i}$, and an error term, $\tau_{i t-1}$,

$$
y_{i t-1}^{*}=x_{i t-1}^{\prime} \beta+\alpha_{i}+\tau_{i t-1} .
$$

The observed outcome, $y_{i t-1}$, can be seen as taking values 0 or 1 dependent on the latent probability of being non-rich, as defined by a cut-off point, $\lambda$. Let us reserve 1 for being rich. Then we have

$$
y_{i t}=\left\{\begin{array}{l}
1 \quad \text { if } y_{i t}^{*} \geq \lambda_{i t} \\
0 \text { else }
\end{array}\right.
$$

Assuming that $\tau_{i t-1}: N\left(0, \sigma_{u}^{2}\right)$, such a model can be estimated as

$$
P\left[y_{i t-1}=0\right]=\Phi\left(-x_{i t-1}^{\prime} \beta-\alpha_{i}\right)
$$


where $\Phi$ is the standard normal cumulative distribution function. Similarly, we can also see the placement in period $t$ for individuals who are non-rich in period $t-1$ as following from the same type of modeling:

$$
y_{i t}^{*}=z_{i t}^{\prime} \gamma+\alpha_{i}+\xi_{i t}
$$

where $z_{i t}^{\prime}$ is a vector of explanatory variables explaining outcome in $t$, given that the individual is nonrich at $t$-1, and $\xi_{i t}$ is an normally distributed error term. This leads to a joint probability for observing both being rich in period $t$ and being non-rich in period $t-1$ :

$$
P\left[y_{i t}=1, y_{i t-1}=0\right]=\Phi_{2}\left(z_{i t-1} \gamma+\alpha_{i},-x_{i t}^{\prime} \beta-\alpha_{i}\right),
$$

where $\Phi_{2}$ is the cumulative distribution function of the bivariate standard normal. Unobserved heterogeneity in equations (3) and (4) is represented by individual specific time invariant effects, $\alpha_{i}$, plus error terms, $\tau_{i t-1}$ and $\xi_{i t}$ in the two equations, respectively. Letting $u_{i t-1}=\alpha_{i}+\tau_{i t-1}$ and $\varepsilon_{i t}=\alpha_{i}+\xi_{i t}$, the approach taken in this study, i.e., focusing on non-causal results, means that the relationship between error terms, $\left(\tau_{i t-1}, \xi_{i t}\right)$, is not explicitly addressed. Obviously, unobservables determining the base year probability to be non-rich are correlated with the unobservables determining the conditional transfer into being rich in period $t$. This is a version of the initial condition problem of dynamic discrete choice models, see Heckman (1981). However, endogeneity problems in this analysis are also due to the key explanatory variable, business ownership, being clearly endogenous with the income hierarchy placement in period $t-1$ and with the placement in period $t$. Thus, given these measurement problems, we interpret results in terms of non-causal relationships, focusing on correlations between income hierarchy movements and business ownership. If we neglect the dependency between error terms, the conditional probability can be seen as,

$$
P\left[y_{i t}=1 \mid y_{i t-1}=0\right]=\frac{\Phi_{2}\left(-x_{i t-1}^{\prime} \beta-\alpha_{i}, z_{i t}^{\prime} \gamma+\alpha_{i}\right)}{\Phi\left(-x_{i t-1}^{\prime} \beta-a_{i}\right)}=\Phi\left(z_{i t}^{\prime} \gamma+\alpha_{i}\right) .
$$

Equation (7) defines the probability of being rich in at $t$, conditional on being non-rich at $t-1$, as related to a number of explanatory variables, including being an owner of a small business. With information from 10 waves of transitions, $\{1993 / 94,1994 / 95, \ldots, 2002 / 2003\}$, we estimate an average correlation between business ownership and transitions into "rich" for the period 1993-2003, when the dual income tax system was in force. A similar type of reasoning generates a corresponding equation for the probability of staying rich, given that the individual was rich in period $t-1$. We use an identical set 
of explanatory variables for the two equations (identical $z$-vectors). Estimations of conditional probabilities or transition rates have, for example, recently been seen in the literature focusing on the low end of the income distribution, explaining low pay dynamics, low income dynamics and poverty dynamics; see for instance Stewart and Swaffield (1999) and Cappellari and Jenkins (2002; 2004).

As seen in Equation (7), the empirical approach allows us to take an individual specific time invariant effect into account when describing the transitions, represented by $\alpha_{i}$. We will treat this as a random effect and estimate equation (7) by the random effects probit model. This means, see e.g., Wooldridge (2002), there is no correlation between observed explanatory variables and the individual

effect, $E\left(\alpha_{i} \mid z_{i}\right)=0$, where $z_{i} \equiv\left(z_{i 1993}, z_{i 1994}, \ldots, z_{i 2003}\right)$. However, note how the estimation of Equation (7) in effect turns the panel into an unbalanced panel, which implies that random effects estimations are only carried out for individuals observed more than one time. This selection may be non-innocent, and is the main reason for also referring to pooled probit estimates (in the Appendix).

\subsection{Descriptive statistics}

Table 9 presents descriptive statistics for the two estimated equations: one for becoming rich and one for staying rich. All figures are averages across the 10 waves that we have information for: $\{1993 / 94,1994$ / 95,..., 2002 / 2003$\}$. Estimations are carried out both for quintile and decile specifications.

There is a large degree of permanence at the high end on the income distribution; on average approximately 80 percent of the people at the upper quintile at year $t$ were there in year $t-1$, whereas as the corresponding figure for the decile specification is 76 percent, see the "Stay rich" columns. Correspondingly, people do not move as frequently into the upper quintile and upper decile, see the "Upward mobility” columns, only 4.9 percent and 2.6 percent on average. 
Table 9. Descriptive statistics for variables used to describe relationships to upward mobility and staying rich, quintile and decile specifications. Average measures for 10 yearly waves, standard deviations in parentheses

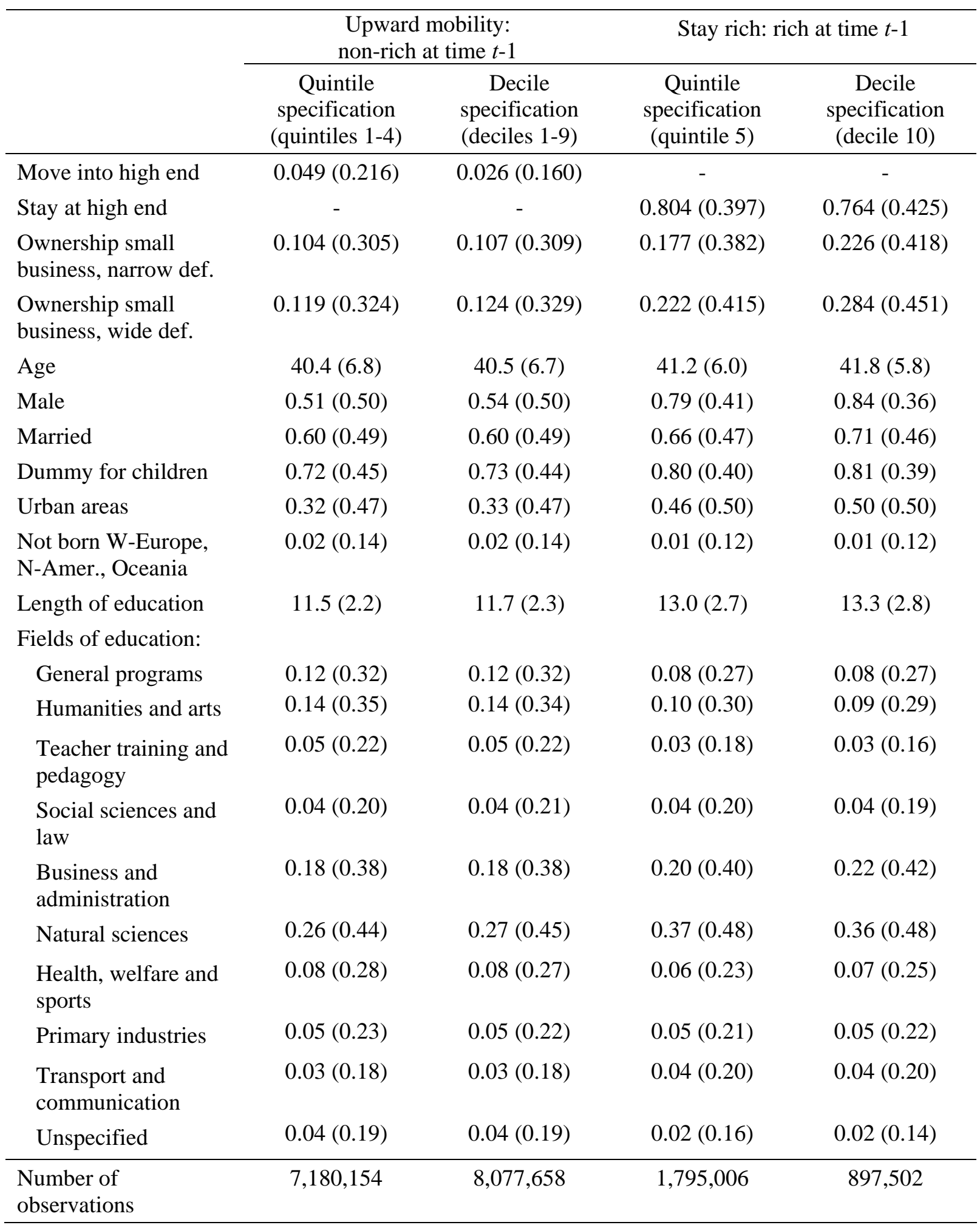




\subsection{Estimation results}

\subsubsection{Ownership of small businesses and upward mobility}

Let us first address the effect of being an owner of a small business on upward mobility. As estimations are based on a random effect probit model and as the key explanatory variable is a dummy variable, we need to describe the procedures by which we identify the effects of the explanatory variables. In the tables we report marginal effects, calculated for predicted probabilities of positive outcomes. ${ }^{11}$ The effect of the discrete variable representing business ownership or not is calculated for a discrete change from 0 to 1 in this dummy variable, holding the other covariates at their means. The estimations also involve time dummies, the coefficients of which are not reported. ${ }^{12}$

Table 10 shows results for two specifications of conditional probabilities or transitions rates: one based on quintiles, transition into the upper quintile (quintile 5) in year $t$ if located in quintile 1-4 in year $t-1$, and one based on deciles, transition into decile 10 in year $t$ if placed in deciles 1-9 in year $t$-1. Independent of specification, and as expected, there is a positive relationship between business ownership and income advancement; using the wider definition of business owners enhances this positive relationship. However, the effect of business ownership and of the wider definition are modest: being a business owner increases the probability for moving into quintile 5 by 3.3 percent on the narrow definition and 3.8 percent on the wide definition. The corresponding estimates for moving upward to decile 10 are 1.3 percent and 1.6 percent on the narrow and wide definition, respectively.

As noted when discussing the mobility tables of Section 3, we may expect to find a stronger relationship between business ownership and upward mobility later in the period 1993-2003. Indeed, estimations restricted to transitions in 2001, 2002 and 2003 do show somewhat stronger effects, 4.8 percent according to the quintile specification for the wide definition of business owners.

\footnotetext{
${ }^{11}$ The xtprobit routine of Stata is used.

${ }^{12}$ All tables report estimates for the proportion of the total variance contributed by the person level variance, rho. When rho is zero, a panel model, such as the random effects model, is not a significant improvement.
} 
Table 10. Relationship between upward mobility and business ownership. Results for marginal effects based on random effects probit estimations of yearly transitions, for two definitions of owners of small businesses. Quintile and decile specifications, standard errors in parentheses

\begin{tabular}{|c|c|c|c|c|}
\hline & \multicolumn{2}{|c|}{ Quintile specification } & \multicolumn{2}{|c|}{ Decile specification } \\
\hline & $\begin{array}{l}\text { Owners of small } \\
\text { businesses, } \\
\text { narrow } \\
\text { definition }\end{array}$ & $\begin{array}{l}\text { Owners of small } \\
\text { businesses, wide } \\
\text { definition }\end{array}$ & $\begin{array}{l}\text { Owners of small } \\
\text { businesses, } \\
\text { narrow } \\
\text { definition }\end{array}$ & $\begin{array}{c}\text { Owners of small } \\
\text { businesses, wide } \\
\text { definition }\end{array}$ \\
\hline $\begin{array}{l}\text { Ownership of small } \\
\text { business }\end{array}$ & $0.033\left(3.4 \times 10^{-4}\right)$ & $0.038\left(3.4 \times 10^{-4}\right)$ & $0.013\left(1.6 \times 10^{-4}\right)$ & $0.016\left(1.7 \times 10^{-4}\right)$ \\
\hline Age & $\begin{array}{l}-2.0 \times 10^{-4} \\
\left(1.0 \times 10^{-5}\right)\end{array}$ & $\begin{array}{l}-2.0 \times 10^{-4} \\
\left(1.0 \times 10^{-5}\right)\end{array}$ & $\begin{array}{c}3.7 \times 10^{-5} \\
\left(1.0 \times 10^{-6}\right)\end{array}$ & $\begin{array}{c}3.7 \times 10^{-5} \\
\left(1.0 \times 10^{-6}\right)\end{array}$ \\
\hline Male & $0.029\left(1.7 \times 10^{-4}\right)$ & $0.028\left(1.7 \times 10^{-4}\right)$ & $0.009\left(7.0 \times 10^{-5}\right)$ & $0.008\left(7.0 \times 10^{-5}\right)$ \\
\hline Married & $-0.006\left(1.2 \times 10^{-4}\right)$ & $-0.006\left(1.2 \times 10^{-4}\right)$ & $\begin{array}{l}-3.3 \times 10^{-4} \\
\left(4.0 \times 10^{-5}\right)\end{array}$ & $\begin{array}{l}-3.8 \times 10^{-4} \\
\left(4.0 \times 10^{-5}\right)\end{array}$ \\
\hline Dummy for children & $0.011\left(1.0 \times 10^{-4}\right)$ & $0.011\left(1.0 \times 10^{-4}\right)$ & $0.002\left(3.0 \times 10^{-5}\right)$ & $0.002\left(3.0 \times 10^{-5}\right)$ \\
\hline Urban areas & $0.011\left(1.5 \times 10^{-4}\right)$ & $0.011\left(1.5 \times 10^{-4}\right)$ & $0.004\left(5.0 \times 10^{-5}\right)$ & $0.004\left(5.0 \times 10^{-5}\right)$ \\
\hline $\begin{array}{l}\text { Not born W-Europe, } \\
\text { N-Amer., Oceania }\end{array}$ & $-0.006\left(2.4 \times 10^{-4}\right)$ & $-0.006\left(2.4 \times 10^{-4}\right)$ & $-0.002\left(6.0 \times 10^{-5}\right)$ & $-0.002\left(6.0 \times 10^{-5}\right)$ \\
\hline Length of education & $0.005\left(3.0 \times 10^{-5}\right)$ & $0.005\left(3.0 \times 10^{-5}\right)$ & $0.001\left(1.0 \times 10^{-5}\right)$ & $0.001\left(1.0 \times 10^{-5}\right)$ \\
\hline \multicolumn{5}{|l|}{$\begin{array}{l}\text { Dummies for fields of } \\
\text { education: }\end{array}$} \\
\hline General progr. & $0.003\left(3.3 \times 10^{-4}\right)$ & $0.003\left(3.3 \times 10^{-4}\right)$ & $0.002\left(1.3 \times 10^{-4}\right)$ & $0.002\left(1.3 \times 10^{-4}\right)$ \\
\hline Humanities and arts & $\begin{array}{c}2.0 \times 10^{-5} \\
\left(2.8 \times 10^{-4}\right)\end{array}$ & $\begin{array}{l}-3.9 \times 10^{-5} \\
\left(2.8 \times 10^{-4}\right)\end{array}$ & $\begin{array}{c}3.6 \times 10^{-4} \\
\left(1.0 \times 10^{-4}\right)\end{array}$ & $\begin{array}{c}3.2 \times 10^{-4} \\
\left(1.0 \times 10^{-4}\right)\end{array}$ \\
\hline $\begin{array}{l}\text { Teacher training and } \\
\text { pedagogy }\end{array}$ & $-0.009\left(1.7 \times 10^{-4}\right)$ & $-0.009\left(1.7 \times 10^{-4}\right)$ & $-0.002\left(5.0 \times 10^{-5}\right)$ & $-0.002\left(5.0 \times 10^{-5}\right)$ \\
\hline $\begin{array}{l}\text { Social sciences and } \\
\text { law }\end{array}$ & $-0.007\left(1.9 \times 10^{-4}\right)$ & $-0.007\left(2.0 \times 10^{-4}\right)$ & $-0.002\left(6.0 \times 10^{-5}\right)$ & $-0.002\left(6.0 \times 10^{-5}\right)$ \\
\hline $\begin{array}{l}\text { Business and } \\
\text { administration }\end{array}$ & $0.006\left(3.4 \times 10^{-4}\right)$ & $0.005\left(3.3 \times 10^{-4}\right)$ & $0.003\left(1.4 \times 10^{-4}\right)$ & $0.003\left(1.3 \times 10^{-4}\right)$ \\
\hline Natural sciences & $0.002\left(2.8 \times 10^{-4}\right)$ & $0.002\left(2.8 \times 10^{-4}\right)$ & $\begin{array}{c}7.7 \times 10^{-4} \\
\left(1.0 \times 10^{-4}\right)\end{array}$ & $\begin{array}{c}7.4 \times 10^{-4} \\
\left(1.0 \times 10^{-4}\right)\end{array}$ \\
\hline $\begin{array}{l}\text { Health, welfare and } \\
\text { sports }\end{array}$ & $-0.003\left(2.5 \times 10^{-4}\right)$ & $-0.003\left(2.5 \times 10^{-4}\right)$ & $\begin{array}{l}-1.5 \times 10^{-4} \\
\left(1.0 \times 10^{-4}\right)\end{array}$ & $\begin{array}{l}-1.3 \times 10^{-4} \\
\left(1.0 \times 10^{-4}\right)\end{array}$ \\
\hline Primary industries & $-0.002\left(2.7 \times 10^{-5}\right)$ & $-0.002\left(2.7 \times 10^{-5}\right)$ & $\begin{array}{l}-1.0 \times 10^{-4} \\
\left(1.0 \times 10^{-4}\right)\end{array}$ & $\begin{array}{l}-1.2 \times 10^{-4} \\
\left(1.0 \times 10^{-4}\right)\end{array}$ \\
\hline $\begin{array}{l}\text { Transport and } \\
\text { communication }\end{array}$ & $0.002\left(3.3 \times 10^{-5}\right)$ & $0.002\left(3.3 \times 10^{-5}\right)$ & $\begin{array}{c}7.5 \times 10^{-4} \\
\left(1.2 \times 10^{-4}\right) \\
\end{array}$ & $\begin{array}{c}7.4 \times 10^{-4} \\
\left(1.2 \times 10^{-4}\right) \\
\end{array}$ \\
\hline Rho & $0.453(0.001)$ & $0.446(0.001)$ & $0.449(0.002)$ & $0.463(0.001)$ \\
\hline LR-test of rho $=0$ & Prob $>=0.000$ & Prob $>=0.000$ & Prob $>=0.000$ & Prob $>=0.000$ \\
\hline
\end{tabular}


Regarding the relationship to other variables, we see that being male, having children, living in an urban area, and length of education are positively correlated with upward mobility, whereas age, being married and birth outside Western Europe, North-America and Oceania are not. The dummy variables for field of education are defined in relation to the omitted reference category, an unspecified broad field of education. Note also that the likelihood ratio test of a non-significant random effect is clearly rejected; the random effects model is therefore preferable to alternatives without individual effects, such as pooled probit. However, as noted earlier, the random effects estimation involves nontrivial restrictions in the sample employed in the estimations, i.e. restricting to individuals represented in more than one wave. Results from pooled probit estimations are shown in Table A1 in the Appendix.

As we see, the parameter estimates for "male" are just below the parameter estimates for small business ownership. Another way of setting parameter estimates for business ownership into perspective is to compare them to a similar random effects estimation of downward mobility, i.e., using the same explanatory variables for transitions from quintiles 2-5 down to quintile 1 . Such estimation generates (positive) parameter values for business ownership of approximately the same size as those featured in Table 10. The present analysis can therefore be said to confirm the uncertain character of income from business ownership, leading to overrepresentation of owners of small businesses at the low and high ends of the income distribution scale, see Table 2 and Table 3.

\subsubsection{The relationship to staying rich}

The next question concerns the extent to which involvement in business ownership increases the probability of staying at the high end of the income distribution scale. Table 11 shows results of random effects probit estimations based on conditional probabilities for staying in the upper quintile or in the upper decile in year $t$, given that the persons were in the same position in year $t-1$. As we see, the relationship is negative according to the quintile specification and positive only after restricting to rich in terms as defined by the decile specification. However, again the parameter estimates are small. The probability of staying rich is higher if the subject is male, married, has children, lives in an urban setting, was born in Western Europe, North America or Oceania, and is well educated. Most importantly, the wider definition of income strengthens the positive relationship for the decile specification and reduces the negative effect according to the quintile alternative.

As measures of upward mobility were compared to downward mobility in the previous section, it is illustrative to compare the estimates of Table 11 to similar estimates from "stay-poor" estimations. Such comparisons reveal that business ownership is positively related to staying at the low end of the income distribution, again confirming the symmetry of relationships to business ownership at both tails of the income distribution. 
Table 11. Relationship between staying rich and business ownership. Results for marginal effects based on random effects probit estimations of yearly transitions, for two definitions of owners of small businesses. Quintile and decile specifications, standard errors in parentheses

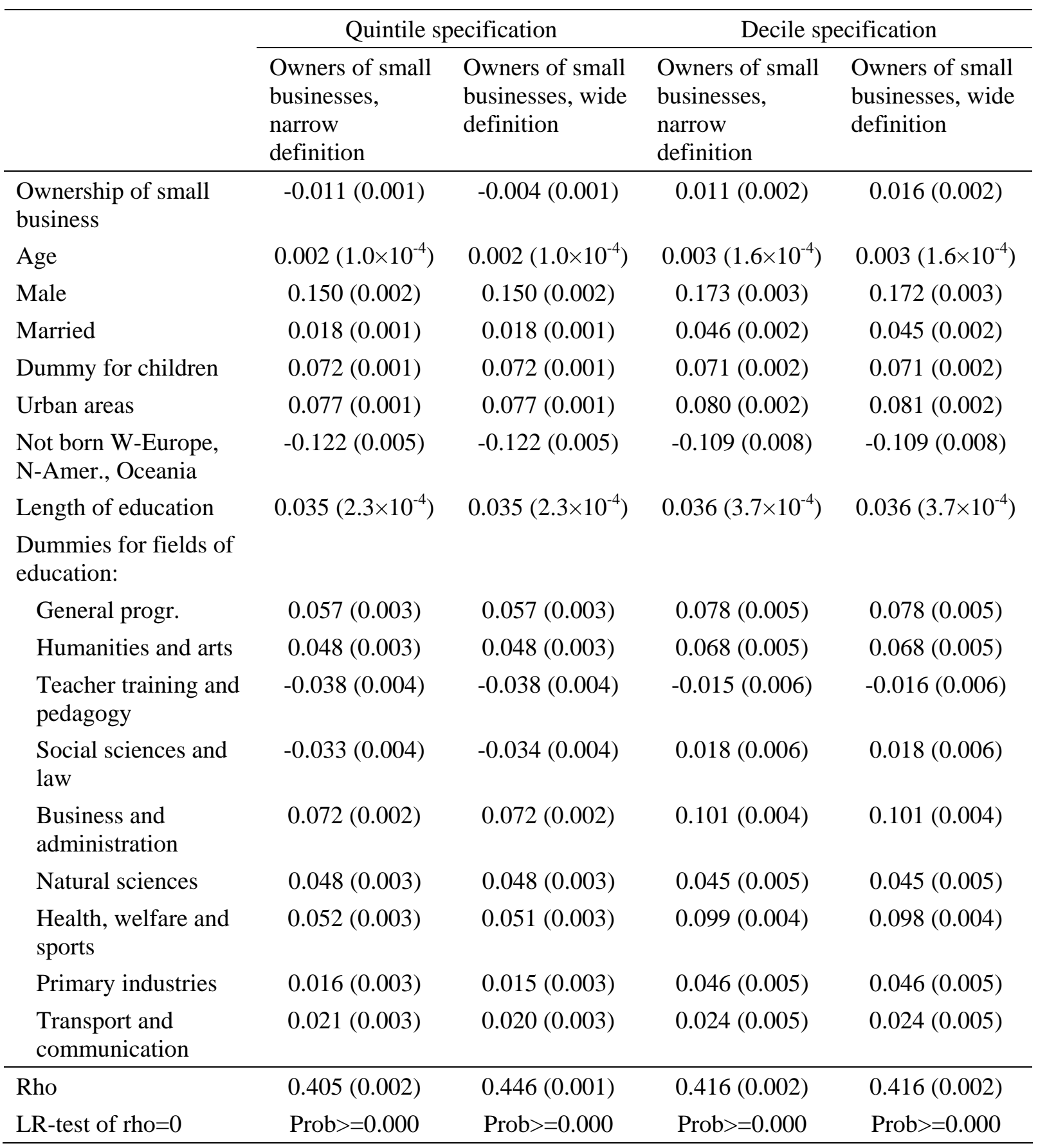

\subsubsection{Alternative categorizations of time periods}

So far, it has been established that business ownership increases the likelihood of upward mobility and stability at the high end of the income distribution scale (the latter only established for the decile 
specification, though). Moreover, employing a wider definition of business owners is found to enhance relationships.

Given indications of an effect of the time frame for measuring incomes on results, see Section 3.3 and Holtz-Eakin et al. (2000), estimations for alternative time period specifications may be illuminating. Table 12 shows the results of an estimation of transition models for a three period specification, transitions between 1993-1996 and 1997-1999 and between 1997-1999 and 20002003. Placements in the income hierarchies are based on aggregated post-tax incomes for these three time periods. With fewer transitions available, a pooled probit estimation is preferred, i.e., no random effects estimation. Thus, the relevant comparisons (in terms of estimates from yearly transitions) for the estimates of Table 12 are estimates presented in table A1 and A2 in the Appendix.

Echoing the results of Table 8, estimates presented in Table 12 show larger differences between correlations according to both the narrow and the wide definitions of business ownership. For instance, for upward mobility, being a business owner now increases the probability for moving into quintile 5 by 4.7 percent according to the narrow definition and by 6.1 percent according to the wide definition. As noted in Section 3.3, the difference between estimates derived from yearly transitions and estimates based on data of longer periods may follow from lagged effects, and pooling of incomes over years may affect incomes of wage earners and business owners differently, especially owners of small businesses who have been involved in shifting the form of the organization. However, the contribution of business ownership to mobility mainly shows that parameter estimates tend to reflect the uncertain character of income from business ownership. As for the yearly specification, the relationship to downward mobility and "staying-poor" have been calculated, and business ownership is correlated to downward mobility and "staying poor" approximately in the same manner as upward mobility and "staying rich" shown in Table 12.

Table 12. The contribution from business ownership to upward mobility and staying rich. Results for marginal effects based on pooled probit estimations for transitions between three periods: 1993-1996, 1997-2000, 2001-2003. Two definitions of owners of small businesses, quintile and decile specifications, standard errors in parentheses

\begin{tabular}{lcccc}
\hline & \multicolumn{2}{c}{ Upward mobility } & \multicolumn{2}{c}{ Staying rich } \\
\cline { 2 - 5 } & $\begin{array}{c}\text { Quintile } \\
\text { specification }\end{array}$ & $\begin{array}{c}\text { Decile } \\
\text { specification }\end{array}$ & $\begin{array}{c}\text { Quintile } \\
\text { specification }\end{array}$ & $\begin{array}{c}\text { Decile } \\
\text { specification }\end{array}$ \\
\hline $\begin{array}{l}\text { Ownership of } \\
\text { small business, } \\
\text { narrow def. }\end{array}$ & $0.047(0.001)$ & $0.031(0.001)$ & $0.035(0.002)$ & $0.045(0.003)$ \\
$\begin{array}{l}\text { Ownership of } \\
\text { small business, } \\
\text { wide def. }\end{array}$ & $0.061(0.001)$ & $0.043(0.001)$ & $0.053(0.002)$ & $0.054(0.001)$ \\
\hline $\begin{array}{l}\text { Number of } \\
\text { observations }\end{array}$ & $1,436,026$ & $1,615,530$ & 359,006 & 179,502 \\
\hline
\end{tabular}




\section{Summary}

The objective of the present study was to discuss solutions to a measurement problem which occurs when the relationship between business ownership and income mobility is explored: as occupational boundaries between wage earners and business owners are vague, it may influence results. In particular, the introduction of a dual income tax system in 1992 accentuated this problem in the Norwegian context, by giving incentives to owners of small businesses to establish widely held firms, thereby shifting occupational status from self-employed (or other types of small businesses) to wage earner. Since Thoresen and Alstadsæter (2008) found that certain features of the dual income tax system in combination with certain features of human capital intensive businesses generated organizational shifting, generating substantial income gains for the people involved, we expected different definitions of business owner, with and without the tax-payers who shifted organizational form, to influence results.

Our main finding is that definitions do influence results. Estimations of random effects transition models for upward mobility and staying rich reveal stronger correlation between business ownership, advancement and maintenance of positions at the top of the income distribution scale (only for the decile specification) on the wide definition, which includes small businesses involved in organizational shifting. Also, the effect from business ownership is found to be stronger for transitions between longer time periods.

However, the positive relationship between business ownership and mobility should not be interpreted as implying that business owners have improved their relative positions over the time period. It mainly reflects higher income mobility of business owners, moving towards and staying at either end of the income distribution. Even though the income positions of owners of small firms are seen as more advantageous under the wide definition of income, the overall results mainly echo the uncertain character of income from small businesses.

\section{References}

Bartholomew, D.J. (1982): Stochastic models for social processes, London: Wiley.

Cappellari, L. and S.P. Jenkins (2002): Who stays poor? Who becomes poor? Evidence from the British household panel survey, The Economic Journal 112, C60-C67.

Cappellari, L. and S.P. Jenkins (2004): Modelling low income transitions, Journal of Applied Econometrics 19, 593-610.

Fairlie, R.W. (2004): "Does business ownership provide a source for upward mobility for blacks and hispanics”, in D. Holtz-Eakin and H.S. Rosen (eds.): Public policy and the economics of entrepreneuship, Cambridge (Massachusetts)/London: The MIT Press. 
Fairlie, R.W. (2005): Entrepreneurship and earning among young adults from disadvantaged families, Small Business Economics 25, 223-236.

Formby, J.P., W.J. Smith and B. Zheng (2004): Mobility measurement, transition matrices and statistical inference, Journal of Econometrics 120, 181-2005.

Hamilton, B.H. (2000): Does entrpreneurship pay? An empirical analysis of the returns to selfemployment, Journal of Political Economy 108, 604-631.

Heckman, J.J. (1981): The incidental paramters problem and the problem of initial conditions in estimating a discrete time-discrete data stochastic process, in C.F. Manski and D. McFadden (eds.): Structural analysis of dicrete data with econometric applications, Cambridge (Massachusetts)/London: The MIT Press.

Holtz-Eakin, D. (2000): Public policy toward entrepreneurship, Small Business Economics 15, 283291.

Holtz-Eakin, D., H.S. Rosen and R. Weathers (2000): Horatio Alger meets the mobility tables, Small Business Economics 14, 243-274.

Jenkins, S.P. (1995): Acounting for income inequality trends: decomposition anlyses for the U.K., 1971-1986, Economica 62, 29-63.

Parker, S.C. (1999): The inequality of employment and self-employment incomes: a decomposition analysis for the U.K., Review of Income and Wealth 45, 263-274.

Parker, S.C. (2004): The economics of self-employment and entrepreneurship, Cambridge (England): Cambridge University Press.

Plesko, G.A. (1995): “Gimme shelter?” Closely held corporations since tax reform, National Tax Journal 48, 409-416.

Prais, S.J. (1955): Measuring social mobility, Journal of the Royal Statistical Society Series A, Part I, 118, 56-66.

Shorrocks, A.F. (1978): The measurement of mobility, Econometrica 46, 1013-1024.

Skoglund, T. (2001): Employment in the Norwegian national accounts, Documents 2001/9, Statistics Norway.

Statistics Norway (2006a): Income statistics for persons and families, http://www.ssb.no/english/subjects/05/01/inntpf_en/.

Statistics Norway (2006b): Stock statistics, http://www.ssb.no/english/subjects/11/01/aksjer_en/.

Statistics Norway (2006c): Wage statistics. Wage totals from end of the year certificate register, http://www.ssb.no/english/subjects/06/05/lonnltreg_en/.

Statistics Norway (2008): http://www.ssb.no/english/subjects/10/02/ifaksje_en/ 
Stewart, M.B. and J.K. Swaffield (1999): Low pay dynamics and transition probabilities, Economica 66, $23-42$.

Sørensen, P.B. (2005): Neutral taxation and shareholder income, International Tax and Public Finance 12, 777-801.

Thoresen, T.O. and Annette Alstadsæter (2008): Shifts in organizational form under a dual income tax system, CESifo Working Papers 2273 (April), Center for Economic Studies, Munich, Germany.

Wooldridge, J.M. (2002): Econometric analysis of cross section and panel data, Cambridge (Massachusetts)/London: The MIT Press. 


\section{Appendix}

Table A1. Relationship between upward mobility and business ownership. Results for marginal effects based on pooled probit estimations of yearly transitions, for two definitions of owners of small businesses. Quintile and decile specifications, standard errors in parentheses

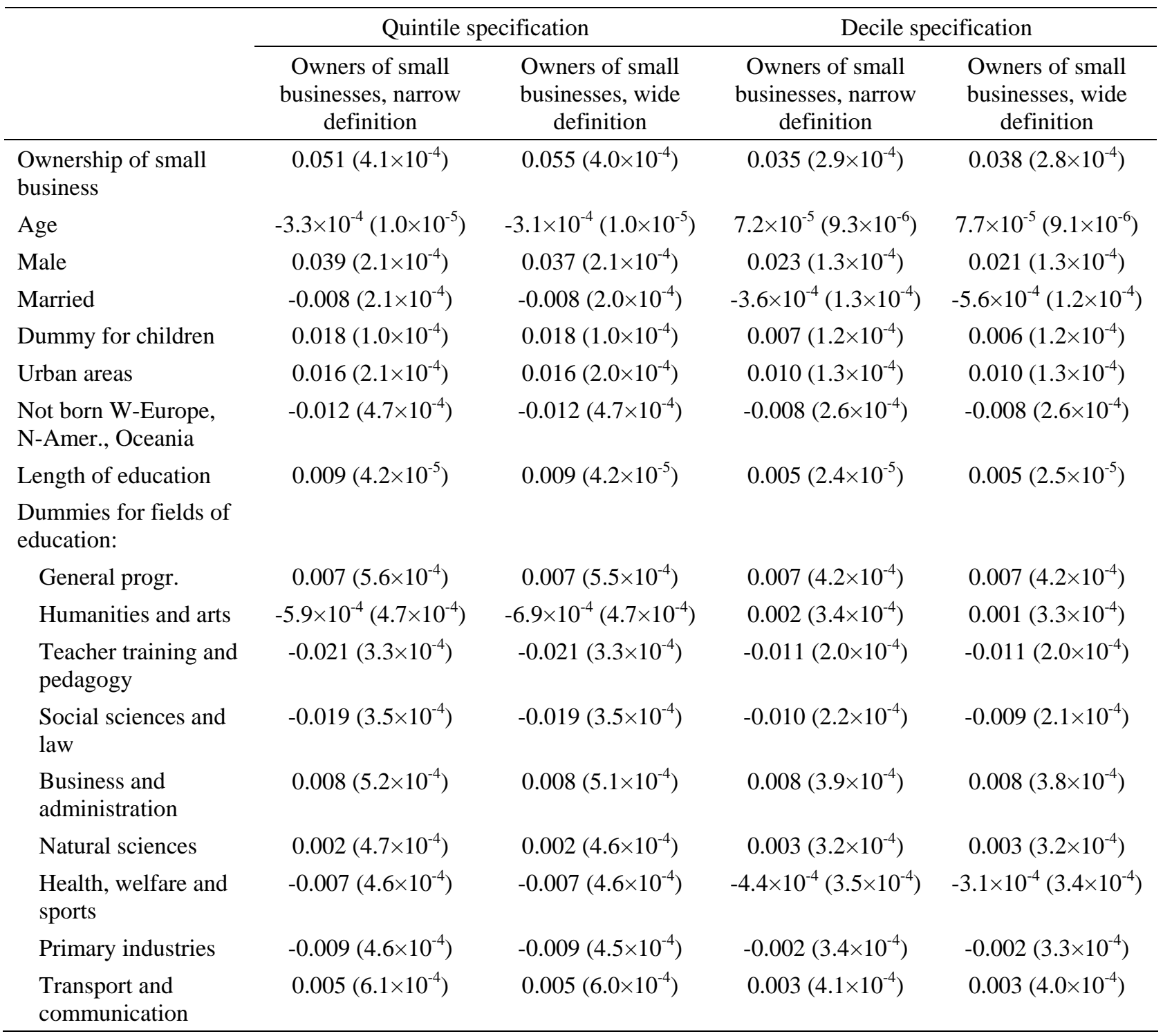


Table A2. Relationship between staying rich and business ownership. Results for marginal effects based on pooled probit estimations of yearly transitions, for two definitions of owners of small businesses. Quintile and decile specifications, standard errors in parentheses

\begin{tabular}{|c|c|c|c|c|}
\hline & \multicolumn{2}{|c|}{ Quintile specification } & \multicolumn{2}{|c|}{ Decile specification } \\
\hline & $\begin{array}{l}\text { Owners of small } \\
\text { businesses, narrow } \\
\text { definition }\end{array}$ & $\begin{array}{l}\text { Owners of small } \\
\text { businesses, wide } \\
\text { definition }\end{array}$ & $\begin{array}{l}\text { Owners of small } \\
\text { businesses, narrow } \\
\text { definition }\end{array}$ & $\begin{array}{l}\text { Owners of small } \\
\text { businesses, wide } \\
\text { definition }\end{array}$ \\
\hline $\begin{array}{l}\text { Ownership of small } \\
\text { business }\end{array}$ & $-0.023(0.001)$ & $-0.015(0.001)$ & $-0.008(0.001)$ & $-0.003(0.001)$ \\
\hline Age & $0.002\left(1.0 \times 10^{-4}\right)$ & $0.004\left(1.0 \times 10^{-4}\right)$ & $0.004\left(1.1 \times 10^{-4}\right)$ & $0.004\left(1.1 \times 10^{-4}\right)$ \\
\hline Male & $0.096(0.001)$ & $0.107(0.002)$ & $0.107(0.002)$ & $0.107(0.002)$ \\
\hline Married & $0.022(0.001)$ & $0.041(0.001)$ & $0.041(0.001)$ & $0.041(0.001)$ \\
\hline Dummy for children & $0.040(0.001)$ & $0.040(0.001)$ & $0.040(0.002)$ & $0.040(0.002)$ \\
\hline Urban areas & $0.051(0.001)$ & $0.052(0.001)$ & $0.050(0.001)$ & $0.050(0.001)$ \\
\hline $\begin{array}{l}\text { Not born W-Europe, N- } \\
\text { Amer., Oceania }\end{array}$ & $-0.084(0.004)$ & $-0.084(0.004)$ & $-0.073(0.006)$ & $-0.073(0.001)$ \\
\hline Length of education & $0.024\left(1.0 \times 10^{-4}\right)$ & $0.024\left(1.7 \times 10^{-4}\right)$ & $0.024\left(2.5 \times 10^{-4}\right)$ & $0.024\left(2.5 \times 10^{-4}\right)$ \\
\hline \multicolumn{5}{|l|}{$\begin{array}{l}\text { Dummies for fields of } \\
\text { education: }\end{array}$} \\
\hline General progr. & $0.057(0.002)$ & $0.056(0.002)$ & $0.067(0.003)$ & $0.067(0.003)$ \\
\hline Humanities and arts & $0.045(0.002)$ & $0.045(0.002)$ & $0.055(0.004)$ & $0.055(0.004)$ \\
\hline $\begin{array}{l}\text { Teacher training and } \\
\text { pedagogy }\end{array}$ & $-0.040(0.003)$ & $-0.040(0.003)$ & $-0.030(0.005)$ & $-0.030(0.005)$ \\
\hline $\begin{array}{l}\text { Social sciences and } \\
\text { law }\end{array}$ & $-0.041(0.003)$ & $-0.041(0.003)$ & $-0.007(0.005)$ & $-0.007(0.005)$ \\
\hline $\begin{array}{l}\text { Business and } \\
\text { administration }\end{array}$ & $0.058(0.002)$ & $0.058(0.002)$ & $0.072(0.003)$ & $0.072(0.003)$ \\
\hline Natural sciences & $0.039(0.002)$ & $0.039(0.002)$ & $0.031(0.004)$ & $0.032(0.004)$ \\
\hline $\begin{array}{l}\text { Health, welfare and } \\
\text { sports }\end{array}$ & $0.051(0.002)$ & $0.051(0.002)$ & $0.075(0.003)$ & $0.074(0.004)$ \\
\hline Primary industries & $0.012(0.003)$ & $0.012(0.003)$ & $0.036(0.004)$ & $0.034(0.004)$ \\
\hline $\begin{array}{l}\text { Transport and } \\
\text { communication }\end{array}$ & $0.014(0.002)$ & $0.014(0.002)$ & $0.007(0.004)$ & $0.006(0.004)$ \\
\hline
\end{tabular}




\section{CESifo Working Paper Series}

for full list see www.cesifo-group.org/wp

(address: Poschingerstr. 5, 81679 Munich, Germany, office@cesifo.de)

2569 Bart Cockx and Matteo Picchio, Are Short-Lived Jobs Stepping Stones to Long-Lasting Jobs?, March 2009

2570 David Card, Jochen Kluve and Andrea Weber, Active Labor Market Policy Evaluations: A Meta-analysis, March 2009

2571 Frederick van der Ploeg and Anthony J. Venables, Harnessing Windfall Revenues: Optimal Policies for Resource-Rich Developing Economies, March 2009

2572 Ondřej Schneider, Reforming Pensions in Europe: Economic Fundamentals and Political Factors, March 2009

2573 Jo Thori Lind, Karl Ove Moene and Fredrik Willumsen, Opium for the Masses? Conflict-Induced Narcotics Production in Afghanistan, March 2009

2574 Silvia Marchesi, Laura Sabani and Axel Dreher, Agency and Communication in IMF Conditional Lending: Theory and Empirical Evidence, March 2009

2575 Carlo Altavilla and Matteo Ciccarelli, The Effects of Monetary Policy on Unemployment Dynamics under Model Uncertainty - Evidence from the US and the Euro Area, March 2009

2576 Falko Fecht, Kjell G. Nyborg and Jörg Rocholl, The Price of Liquidity: Bank Characteristics and Market Conditions, March 2009

2577 Giorgio Bellettini and Filippo Taddei, Real Estate Prices and the Importance of Bequest Taxation, March 2009

2578 Annette Bergemann and Regina T. Riphahn, Female Labor Supply and Parental Leave Benefits - The Causal Effect of Paying Higher Transfers for a Shorter Period of Time, March 2009

2579 Thomas Eichner and Rüdiger Pethig, EU-Type Carbon Emissions Trade and the Distributional Impact of Overlapping Emissions Taxes, March 2009

2580 Antonios Antypas, Guglielmo Maria Caporale, Nikolaos Kourogenis and Nikitas Pittis, Selectivity, Market Timing and the Morningstar Star-Rating System, March 2009

2581 António Afonso and Christophe Rault, Bootstrap Panel Granger-Causality between Government Budget and External Deficits for the EU, March 2009

2582 Bernd Süssmuth, Malte Heyne and Wolfgang Maennig, Induced Civic Pride and Integration, March 2009 
2583 Martin Peitz and Markus Reisinger, Indirect Taxation in Vertical Oligopoly, March 2009

2584 Petra M. Geraats, Trends in Monetary Policy Transparency, March 2009

2585 Johannes Abeler, Armin Falk, Lorenz Götte and David Huffman, Reference Points and Effort Provision, March 2009

2586 Wolfram F. Richter, Taxing Education in Ramsey’s Tradition, March 2009

2587 Yin-Wong Cheung, Menzie D. Chinn and Eiji Fujii, China's Current Account and Exchange Rate, March 2009

2588 Alexander Haupt and Silke Uebelmesser, Voting on Labour-Market Integration and Education Policy when Citizens Differ in Mobility and Ability, March 2009

2589 Hans Jarle Kind, Marko Koethenbuerger and Guttorm Schjelderup, Should UtilityReducing Media Advertising be Taxed?, March 2009

2590 Alessandro Cigno, How to Avoid a Pension Crisis: A Question of Intelligent System Design, March 2009

2591 Helmut Lütkepohl and Fang Xu, The Role of the Log Transformation in Forecasting Economic Variables, March 2009

2592 Rainald Borck, Hyun-Ju Koh and Michael Pflüger, Inefficient Lock-in and Subsidy Competition, March 2009

2593 Paolo M. Panteghini, On the Equivalence between Labor and Consumption Taxation, March 2009

2594 Bruno S. Frey, Economists in the PITS?, March 2009

2595 Natalie Chen and Dennis Novy, International Trade Integration: A Disaggregated Approach, March 2009

2596 Frédérique Bec and Christian Gollier, Term Structure and Cyclicity of Value-at-Risk: Consequences for the Solvency Capital Requirement, March 2009

2597 Carsten Eckel, International Trade and Retailing, March 2009

2598 Gianni De Nicolò and Iryna Ivaschenko, Global Liquidity, Risk Premiums and Growth Opportunities, March 2009

2599 Jay Pil Choi and Heiko Gerlach, International Antitrust Enforcement and Multi-Market Contact, March 2009

2600 Massimo Bordignon and Guido Tabellini, Moderating Political Extremism: Single Round vs Runoff Elections under Plurality Rule, April 2009 
2601 Ana B. Ania and Andreas Wagener, The Open Method of Coordination (OMC) as an Evolutionary Learning Process, April 2009

2602 Simon Gächter, Daniele Nosenzo, Elke Renner and Martin Sefton, Sequential versus Simultaneous Contributions to Public Goods: Experimental Evidence, April 2009

2603 Philippe Jehiel and Andrew Lilico, Smoking Today and Stopping Tomorrow: A Limited Foresight Perspective, April 2009

2604 Andreas Knabe, Steffen Rätzel, Ronnie Schöb and Joachim Weimann, Dissatisfied with Life, but Having a Good Day: Time-Use and Well-Being of the Unemployed, April 2009

2605 David Bartolini and Raffaella Santolini, Fiscal Rules and the Opportunistic Behaviour of the Incumbent Politician: Evidence from Italian Municipalities, April 2009

2606 Erkki Koskela and Jan König, Can Profit Sharing Lower Flexible Outsourcing? A Note, April 2009

2607 Michel Beine, Frédéric Docquier and Çağlar Özden, Diasporas, April 2009

2608 Gerd Ronning and Hans Schneeweiss, Panel Regression with Random Noise, April 2009

2609 Adam S. Booij, Bernard M.S. van Praag and Gijs van de Kuilen, A Parametric Analysis of Prospect Theory's Functionals for the General Population, April 2009

2610 Jeffrey R. Brown, Julia Lynn Coronado and Don Fullerton, Is Social Security Part of the Social Safety Net?, April 2009

2611 Ali Bayar and Bram Smeets, Economic, Political and Institutional Determinants of Budget Deficits in the European Union, April 2009

2612 Balázs Égert, The Impact of Monetary and Commodity Fundamentals, Macro News and Central Bank Communication on the Exchange Rate: Evidence from South Africa, April 2009

2613 Michael Melvin, Christian Saborowski, Michael Sager and Mark P. Taylor, Bank of England Interest Rate Announcements and the Foreign Exchange Market, April 2009

2614 Marie-Louise Leroux, Pierre Pestieau and Gregory Ponthiere, Should we Subsidize Longevity?, April 2009

2615 Ronald MacDonald, Lukas Menkhoff and Rafael R. Rebitzky, Exchange Rate Forecasters' Performance: Evidence of Skill?, April 2009

2616 Frederick van der Ploeg and Steven Poelhekke, The Volatility Curse: Revisiting the Paradox of Plenty, April 2009 
2617 Axel Dreher, Peter Nunnenkamp, Hannes Öhler and Johannes Weisser, Acting Autonomously or Mimicking the State and Peers? A Panel Tobit Analysis of Financial Dependence and Aid Allocation by Swiss NGOs, April 2009

2618 Guglielmo Maria Caporale, Roman Matousek and Chris Stewart, Rating Assignments: Lessons from International Banks, April 2009

2619 Paul Belleflamme and Martin Peitz, Asymmetric Information and Overinvestment in Quality, April 2009

2620 Thomas Dohmen, Armin Falk, David Huffman and Uwe Sunde, Are Risk Aversion and Impatience Related to Cognitive Ability?, April 2009

2621 Yin-Wong Cheung and Xingwang Qian, The Empirics of China's Outward Direct Investment, April 2009

2622 Frédérique Bec and Christian Gollier, Assets Returns Volatility and Investment Horizon: The French Case, April 2009

2623 Ronnie Schöb and Marcel Thum, Asymmetric Information Renders Minimum Wages Less Harmful, April 2009

2624 Martin Ruf and Alfons J. Weichenrieder, The Taxation of Passive Foreign Investment Lessons from German Experience, April 2009

2625 Yao Li, Borders and Distance in Knowledge Spillovers: Dying over Time or Dying with Age? - Evidence from Patent Citations, April 2009

2626 Jim Malley and Ulrich Woitek, Technology Shocks and Aggregate Fluctuations in an Estimated Hybrid RBC Model, April 2009

2627 Jin Cao and Gerhard Illing, Endogenous Systemic Liquidity Risk, April 2009

2628 Thiess Buettner and Bjoern Kauder, Revenue Forecasting Practices: Differences across Countries and Consequences for Forecasting Performance, April 2009

2629 Håkan Selin, The Rise in Female Employment and the Role of Tax Incentives - An Empirical Analysis of the Swedish Individual Tax Reform of 1971, April 2009

2630 Nick Johnstone and Ivan Hascic, Environmental Policy Design and the Fragmentation of International Markets for Innovation, April 2009

2631 Spiros Bougheas, Richard Kneller and Raymond Riezman, Optimal Education Policies and Comparative Advantage, April 2009

2632 Jay Pil Choi and Heiko Gerlach, Multi-Market Collusion with Demand Linkages and Antitrust Enforcement, April 2009

2633 Thor O. Thoresen, Income Mobility of Owners of Small Businesses when Boundaries between Occupations are Vague, April 2009 